Cornell Law Library

Scholarship@Cornell Law: A Digital Repository

Cornell Law School Graduate Student Papers

Cornell Law Student Papers

$12-14-2006$

\title{
The Definition and Jurisdiction of the Crime of Aggression and the International Criminal Court
}

Buhm-Suk Baek

Cornell LawSchool, baek4@hanafos.com

Follow this and additional works at: http://scholarship.law.cornell.edu/lps_papers

Part of the International Law Commons, and the Jurisdiction Commons

\section{Recommended Citation}

Baek, Buhm-Suk, "The Definition and Jurisdiction of the Crime of Aggression and the International Criminal Court" (2006). Cornell Law School Graduate Student Papers. Paper 19.

http://scholarship.law.cornell.edu/lps_papers/19 
The Definition and Jurisdiction of the Crime of Aggression and the International Criminal Court

By

Buhm-Suk Baek

December 2006 


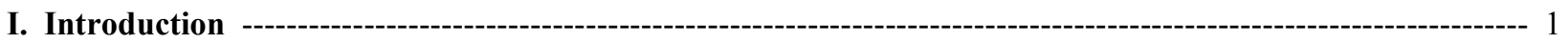

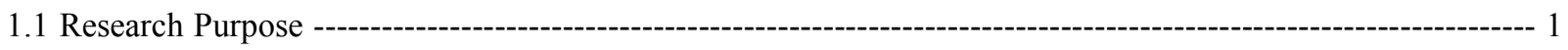

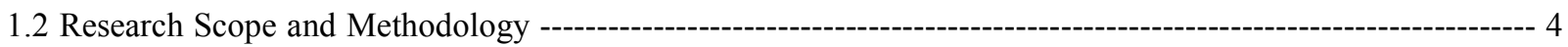

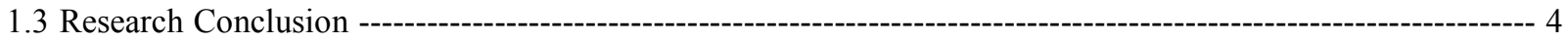

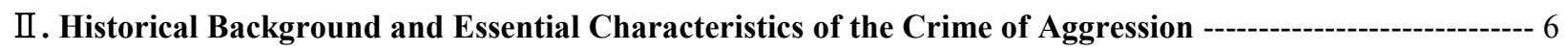

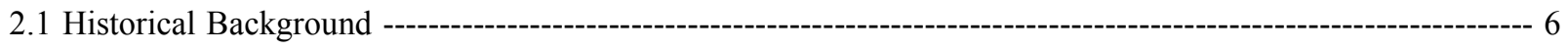

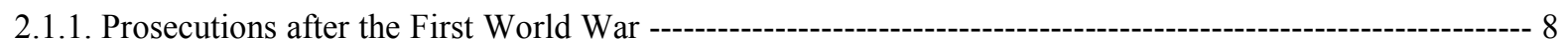

2.1.2. Work of the United Nations War Crimes Commission and the London Conference ---:---10

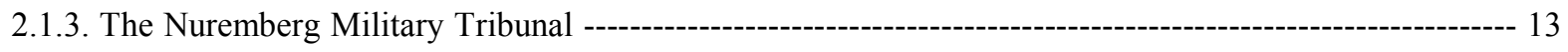

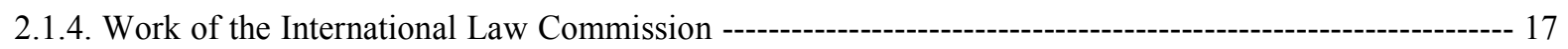

2.1.5. The General Assembly Resolution 3314(XXIX) of 1974 on the Definition of Aggression ----------- 19

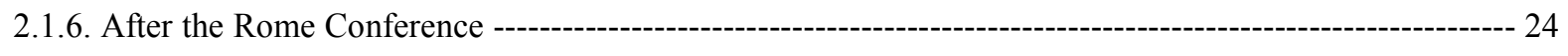

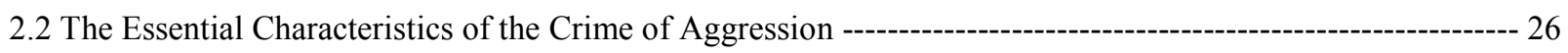

2.2.1. The Act of Aggression and the Crime of Aggression --:-י-:-

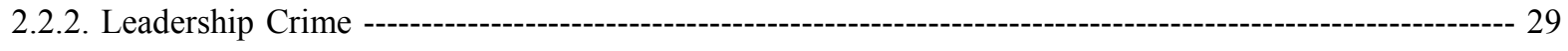

2.2.3. Manifest violation of the Charter of the United Nations -

2.2.4. Compliance with the Principle of legality ---

III. Definition of the Crime of Aggression -

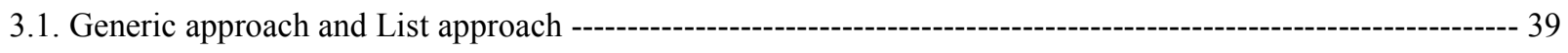

3.2. Threshold of the Crime of Aggression and the Customary International Law ---

3.3. Various Proposals from the Preparatory Commission for the International Criminal Court ---------------- 47

3.4. Post-Rome Statute, Definitional issues from the Special Working Group on the Crime of Aggression ------ 54

3.5. Elements of the Crime of Aggression -- 
3.5.1. Actus reus (Material Elements) --- 60

3.5.2. Mens rea (Mental Elements) --- 62

3.6. Conclusion: Harmonization of Positions ---o- 63

IV. Jurisdiction of the Crime of Aggression -

4.1. The respective roles of the International Criminal Court and the Security Council in Determining an Act of

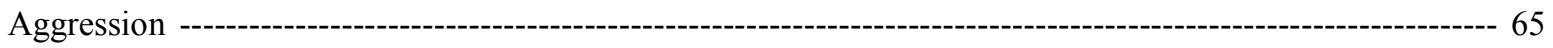

4.2. The Problem of Politicization --- 68

4.3. Discussion of the various Proposals from the Preparatory Commission ---

4.4. Post-Rome Statute: Issues from the Special Working Group on the Crime of Aggression ---a---- 74

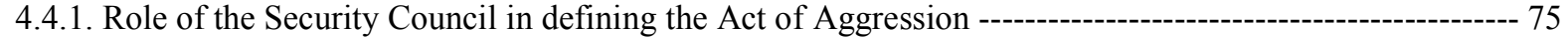

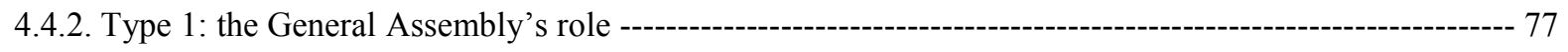

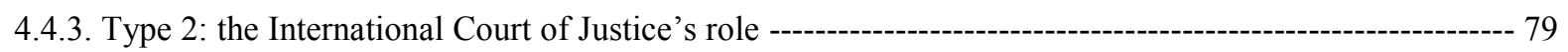

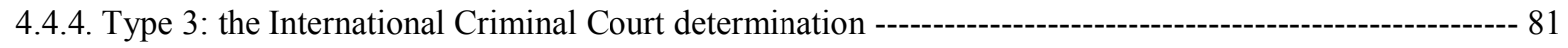

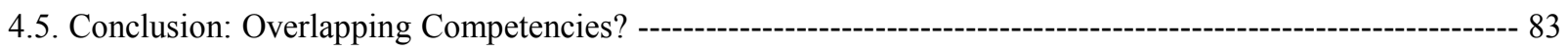

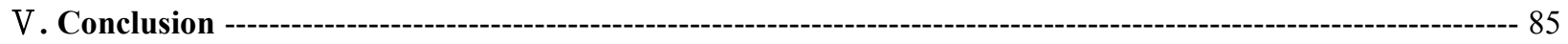

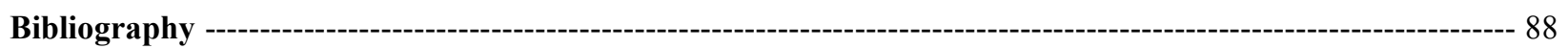

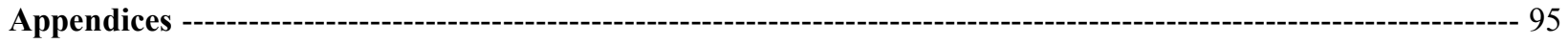




\section{I . Introduction}

\subsection{Research Purpose}

The United Nations Diplomatic Conference of Plenipotentiaries on the Establishment of an International Criminal Court (hereafter Rome Conference) that was held in Rome to establish the International Criminal Court (hereafter ICC) in 1998 finally adopted the Rome Statute with the participation of 160 countries. The Rome Statute of the ICC ${ }^{1}$ entered into force on 1 July 2002 and has been ratified by 100 States. What was considered not so long ago merely a dream of a few people has become a reality after the strenuous efforts of the UN over 50 years. The challenge is now for the Court to concretely establish its authority as an indispensable institution to fight impunity and contribute to justice and peace in world society.

However, one central issue still remains unresolved in the Rome Status. It is the crime of aggression. It is stated in article 5 paragraph 2 of the Statute as following:

The Court shall exercise jurisdiction over the crime of aggression once a provision is adopted in accordance with articles 121 and 123 defining the crime and setting out the conditions under which the Court shall exercise jurisdiction with respect to this crime. ${ }^{2}$

Countries that participated in the Rome Conference agreed to that compromise just in order to secure the conclusion of the Statute after they had reached a deadlock over the crime of aggression. ${ }^{3}$ Adoption of the Rome statute without containing an applicable provision on the crime of aggression, once expressed as the "Supreme International Crime,"4 was a main defect in the Statute. Without the punishment of the crime of aggression, the ICC

${ }^{1}$ Rome Statute of the International Criminal Court, U.N. Doc. A/CONF.183/9

2 Ibid. Art. 5.2 on "Crimes within the Jurisdiction of the Court"

${ }^{3}$ By the last days of the Rome Conference, the picture was very somber. A comment by its bureau on the issue of aggression stated that if generally accepted provisions on its inclusion in the Statute were not developed by interested delegations by the close of 13 July 2001, it will propose that the interest in addressing these crimes by reflected in some other manner, for example, by a protocol or review conference. Several delegations, particularly the representative of the European Union, supported the bureau's proposal. However, other delegations, including Croatia, Egypt, Ghana, Iran and Syria considered unacceptable the noninclusion of that crime, which was part of a decision by the Non-Aligned Movement in its recent ministerial meeting in Colombia. Press Release, L/ROM/16, 13 July 1998, quoted in Mohammed M. Gomaa, "The Definition of the Crime of Aggression and the ICC Jurisdiction over that Crimes" 55 in The International Criminal Court and the Crime of Aggression, ed. Mauro Politi and Giuseppe Nesi (Ashgate, 2004) At present, a strong preference was voiced not for the separate instrument, but for the integration in the Statute through modifications to it concerning the crime of aggression. Third session, Special Working Group on the Crime of Aggression, U.N. Doc. ICC=ASP/3/SWGCA/INF.1 2004, p7.

4 The "supreme international crime" expression was used by the judges in the international military tribunal (IMT) at Nuremberg. 
would not really have the ultimate, long-awaited international criminal jurisdiction.

Surely, the definition and jurisdiction of the crime of aggression has always been an extremely difficult issue to settle. The history of the search for an appropriate and effective definition and jurisdiction of the crime of aggression will be reviewed in this paper; it is not a purely legal issue, but it is intertwined with political elements. The research objective of this thesis is to clarify the terms of the ongoing debate over the crime of aggression, and to facilitate a better understanding about the crime of aggression, in an ad hoc working group open to all member states of the U.N. ${ }^{5}$ It is important to confirm the current controversial issues of the crime of aggression and present a desirable definition and jurisdiction of it. A credible, carefully discussed, precise definition and jurisdictions of the crime of aggression, one that reflects customary international law and respects the U.N. Charter's integrity and the Security Council's responsibility for the maintenance of international peace and security, would enhance the prospects to define the crime of aggression in the Rome Statute and the possibility of other U.N. member states' ratifying it, including the U.S. Also, it would strengthen the prospects for the eventual successful prosecution of crimes of aggression. ${ }^{6}$

\subsection{Research Scope and Methodology}

First, this paper will review and analyze the general characteristics of the crime of aggression and the historical background of the crime of aggression (from the Nuremberg Military Tribunal to the Rome Statute) in part II. Part III covers the definition of the crime of aggression in light of proposals in the Preparatory Commission (from $1^{\text {st }}$ to $10^{\text {th }}$ ) and discussions in the ad hoc working group (from $1^{\text {st }}$ to $4^{\text {th }}$ ) and elements of this crime. Part IV discusses

Also General Assembly announced it as "the gravest of all crimes against peace and security throughout the world." GA Res. $380(V)$ of 17 November 1950, quoted in William A. Schabas, "Origins of the Criminalization of Aggression: how crimes against peace became the 'supreme international crime' 29 in The International Criminal Court and the Crime of Aggression, ed. Mauro Politi and Giuseppe Nesi (Ashgate, 2004)

5 The Assembly of States Parties to the Rome Statute decided to establish 'special working group on the crime of aggression' in 7, February 2003. First Session (First and Second Resumptions) Draft Report of the Assembly of States Parties to the Rome Statute of the International Criminal Court, U.N. Doc. ICC-ASP/1/L.5 2003. First and second session of this working group was held in September 2003, and third session in 21-23, June 2004 and fourth session in 13-15, June 2005.

${ }^{6}$ If there is an agreement on the definition and the conditions for the jurisdiction of the crime of aggression, it can be adopted based on the procedure of amendments on article 121 and 122 of the Statute, after 1 July 2009. Tae-Hyun Choi, "Definition of the Crime of Aggression within the Jurisdiction of the International Criminal Court," Journal of KSIL 47, no.3 (2002): $211-212$. 
the relationship between the ICC and the Security Council from the various points of view concerning the competence of ICC and Security Council, under the U.N. Charter. Finally, through these procedures, this paper will confirm and inquire the current moot issues and suggests desirable a definition and conditions of the crime of aggression in part $\mathrm{V}$.

\subsection{Research Conclusion}

Concerning the definition of the crime of aggression, this paper concludes that first the definition of this crime should follow the "generic approach." Second, the crime of aggression and the act of aggression should be separately stipulated in the definition. That is, the crime of aggression should contain the provisions included in the Nuremberg Charter and also reflect the general recognition on it developed up the point of current circumstances. The act of aggression should follow the provisions of precedents such as resolution 3314(XXIX) of 1974 and the ILC Draft Code of Crimes against the Peace and Security of Mankind 1996. Third, the definition of the crime of aggression should comply with the principle of legality. Thus essential material and mental elements of crime should be included in it.

Concerning the jurisdiction of the Crime of aggression, this paper concludes that first the Security Council's primary responsibility for determining the existence of the state aggression should be confirmed. Second, the Security Council's exclusive right to make such determinations should be denied and there should be a provision which make legally possible for the General Assembly of the United Nations or the International Court of Justice to make such determinations in case of absence of the determination from the Security Council. Third, to decide whether to give such secondary right to the General Assembly of the United Nations or the International Court of Justice should be settled by a political compromise through a structured and clear debate and the room for such debate should be opened not only to the state party to the Rome Statute, but also to all UN members. 


\section{Historical Background and the Essential Characteristics of the Crime of Aggression}

\subsection{Historical Background}

In October 1943, the Allied Powers launched the United Nations War Crimes Commission. As the name of the Commission suggested, it was to prepare for the prosecution of "war crimes." As the deliberations progressed, during 1944, the expert members of the Commission began to explore the possibility of including the waging of aggressive war within the jurisdiction of their work on war crimes. However, in December 1944, it decided to exclude this difficult subject. ${ }^{7}$

Six months later, such opinions dramatically changed. The London Conference authorized the momentous trial of the Nazi leadership at Nuremberg on the basis of both war crimes and crimes against peace, as well as crimes against humanity. ${ }^{8}$ The final judgment of the International Military Tribunal, discussing the nature of crimes against peace, stated that "to initiate a war of aggression, therefore, is not only an international crime; it is the supreme international crime differing only from the war crimes in that it contains within itself the accumulated evil of the whole." It shows that the acts of aggression which were not considered to be punishable by the international community, had become eventually the supreme international crime. ${ }^{10}$

As commented earlier, the Statute of the ICC includes "aggression" within its jurisdiction. But, the definition and the conditions to exercise jurisdiction of the crime of aggression is still being debated and no agreement has been reached. Debates about these issues began only slowly after the Rome Conference, but appears now to be taken seriously. It is interesting that the debates both at Rome Conference and since then have a similarity to the disputes in 1944 and 1945 which will be reviewed in part 2.1.2.

One more thing to point out is that no states have national criminal legislation governing aggression within the framework of ordinary offences that are found in their criminal codes, such as murder, rape and so on. ${ }^{11}$

\footnotetext{
7 William A. Schabas, 17-18.

${ }^{8}$ In-Sub, Chung, Understanding of International Law (Seoul: Hongmun-sa, 1996) 280-281.

${ }^{9}$ United states of America et al. v. Goering et al., International Military Tribunal, Judgment, 30 September $\sim 1$ October 1946,41 Am J. Int'1 L. 172 (1947) 186, quoted in William A. Shabas, 18.

${ }^{10}$ In-Sub, Chung, 282.

11 William A. Schabas, 18.
} 
Practically all states party to the Rome Statute are either "unwilling or unable genuinely" to carry out investigations or prosecutions of the crime of aggression. ${ }^{12}$ Also, no one suggests that aggression is the type of crime for which universal jurisdiction shall be exercised as a customary international law. Thus, the discussions and debates on the crime of aggression in ICC are to a large extent an exercise in the progressive development of international law, rather than in its codification. ${ }^{13}$

The circumstances in establishing the International Military Tribunal at Nuremberg resemble the current situation to discuss the crime of aggression under the jurisdiction of ICC. Perhaps today's debate on the crime of aggression is the outcome of the endless efforts by the international community since the Nuremberg tribunal. Therefore, the past events and progress concerning the crime of aggression related with current issues will be discussed below in this part II.

\subsubsection{Prosecutions after the First World War}

Officially the concept of the individual responsibility for the international criminal prosecution on the war of aggression begins to develop after the First World War. ${ }^{14}$ The Treaty of Versailles intended the prosecution before Allied Power military tribunals of German combatants charged with "violation of the laws and customs of war" in articles 228 to $230 .^{15}$ Also in article 227 of the Treaty of Versailles, it stated that "the Allied and Associated Powers publicly arraign William II of Hohenzollern, formerly German Emperor, for a supreme offence against international morality and the sanctity of treaties."

However, theses provisions did not establish rights and obligations of the States parties. It is purely declaratory. Also article 227 of the Treaty of Versailles did not use the term "aggression" or "crimes against peace." It is because at that time, these were not considered to be acts contrary to international law, let alone subject to

\footnotetext{
${ }_{12}$ Rome Statute of the International Criminal Court, Art. 17.1.a.

13 '.....on of lex ferenda rather than lex lata.....' quoted in William A. Schabas, 19.

${ }^{14}$ Yoram Dinstein, War, Aggression and Self-Defence (Cambridge University Press, 2001) 106.

${ }^{15}$ William A. Schabas, 19.

${ }^{16}$ Ibid.
} 
individual prosecution. ${ }^{17}$

But it is undeniable that this provision was targeted at military and civilian leaders for the waging of a war illegally, that is, in violation of treaties of peace or non-aggression and it may be the antecedent of the Charter of the International Military Tribunal at Nuremberg. ${ }^{18}$

During the war years in early 1900s, much progress was made in the prohibition of aggressive war and the important outcome was the Kellogg-Briand Pact of $1928 .{ }^{19}$ But this Pact had various limitations and interpretations by the state parties and had no legal binding force ${ }^{20}$ and as a result, there was no room to discuss the concept of individual criminal responsibility under the international law.

\subsubsection{Work of the United Nations War Crimes Commission and the London Conference}

The United Nations War Crimes Commission was established at a Diplomatic Conference convened at the Foreign Office in London on 20 October $1943 .^{21}$ Most of the Allies except the Soviet Union participated actively in its activities for future war criminal prosecutions as well as preparation of their legal aspects. At one point, the Commission actually drafted a statute of a future international criminal court. ${ }^{22}$

The most important issue discussed by the Commission was the question of whether aggressive war amounted to a criminal act. ${ }^{23}$ Most of the representatives from the Allies in the Commission considered that the State itself could not be the subject of criminal liability, and that consequently aggressive war could not be

\footnotetext{
${ }^{17}$ Quincy Wright, "Changes in the Conception of War," 18 Am J. Int'1 L. (1924) 755; Quincy Wright, "The Concept of Aggression in International Law,” 29 Am. J. Int’1 L. (1935) 373, quoted in William A. Schabas, 21.

18 Ibid.

19 In-Sub, Chung, 275-276, 279.

20 Dae-Soon, Kim, International Law (Seoul: Parkyoung-sa, 2005) 994.

21 William A. Schabas, 22-23.

22 The Commission was displaced in mid-1945, when the initiative for international criminal prosecution was taken up by the four powers at the London Conference. United Nations War Crimes Commission, History of the United Nations War Crimes Commission and the Development of the Laws of War, (London: His Majesty's Stationery Office, 1948) 107-118, quoted in William Schabas, 22-23.

${ }^{23}$ Ibid.
} 
considered a crime on an individual level. ${ }^{24}$ It was clearly stated in its report: "Acts committed by individuals merely for the purpose of preparing for and launching aggressive war, are, lege lata, not "war crimes." ${ }^{25}$ Such reports were misinterpreted by public opinion as there would be a possibility to have no prosecution on the Nazis, and as a result, opposition to the concept of prosecution for waging aggressive war led to a general rejection of the criminality of the Nazi leaders. ${ }^{26}$

However, the Commission did not resolve the question until after the London Conference of the four powers - the United States of America, the United Kingdom, France and the Soviet Union- had decided that "crimes against peace" should be part of the subject-matter jurisdiction of the International Military Tribunal at Nuremberg. ${ }^{27}$

The concept of wars of aggression, which was not even considered as a crime in times of the Treaty of Versailles, was newly reconsidered by the international community after experiencing the First and Second World War. Such progress became the foundation to strengthen the article 2 paragraph 4 of the UN Charter on the prohibition of the use of force. ${ }^{28}$

The goal of the United Nations War Crimes Commission and of the London Conference was to punish the Nazis, and criminalization of aggressive war seemed the secure way for this to happen. The circumstance was different from that of the Rome Conference in 1998, which renounced any possibility of prosecuting past crimes, and intended to govern only conduct in the future. Although it can be an overstatement to argue that there were no political agendas at Rome. ${ }^{29}$

The uncertainty about the role of aggression within the overall structure of international criminal law is not only characteristic of the debate that immediately preceded International Military Tribunal at Nuremberg, but it is also manifested in the approach to the issue in the decades that were to follow. ${ }^{30}$ The failure of the United Nations War Crimes Commission to even take a position on whether or not aggressive war should be a crime seems

\footnotetext{
${ }^{24}$ Ibid, 24.

25 Ibid.

${ }^{26}$ Arieh J. Kochavi, Prelude to Nuremberg, Allied War Crimes Policy and the Question of Punishment (London: Univ. of North Carolina Press, 1998) 97.

27 William A. Schabas, 26.

${ }^{28}$ Ibid, 29.

${ }^{29}$ Rome Statute of the International Criminal Court, Art.11.

${ }^{30}$ William A. Schabas, 31.
} 
remarkably similar to the hesitations at the Rome Conference, more than 50 years later. ${ }^{31}$

In the London Conference, it was clear whom the Allies wanted to punish, but they were unsure whether this was consistent with principles of international law. At the Rome Conference, there is less concern with the latter, and rather more with the potential targets of prosecutions for aggression. We live at a time when one superpower dominates international relations in both a political and military sense. And it may makes difficult to reach a consensus definition of the crime of aggression and on the conditions under which it may be prosecuted as the concept of common enemy has been obscured and the terrorism become a hot issue.

Perhaps the most useful historical lesson can be that we should not forget the fact that such a hardness to make a compromise on certain issues of the crime of aggression is as true today as it was then. Thus, the history concerning the crime of aggression will be reviewed in greater detail below.

\subsubsection{The Nuremberg Military Tribunal}

The representatives of the four Allied Powers convened in London from 26 June to 8 August 1945, at the International Conference on Military Trials with a view to reaching a unified position on the law and procedure for what was to become the International Military Tribunal at Nuremberg. ${ }^{32}$ As commented earlier, they were confronted with the most problematic and controversial issue of the criminality of aggressive war and the fact that aggression was a state crime. Accordingly, they did not venture to introduce a crime of aggression committed by the individual itself. That led to their adoption of a formula that established the legal nexus between a "war of aggression" and the act of the individual implicated in it. ${ }^{33}$

Article VI of the Charter of the International Military Tribunal of Nuremberg (hereafter Nuremberg

\footnotetext{
31 Eventually, the Commission took a position on the subject, but only after the London Conference as commented earlier. A resolution adopted on 30 January 1946 declared that "crimes against peace and crimes against humanity, as referred to in the Four Power Agreement of August $8^{\text {th }}, 1946$ (i.e. the Nuremberg Charter), were war crimes within the jurisdiction of the Commission." United Nations War Crimes Commission, 187 quoted in William A. Schabas, 31.

32 Mohammed M. Gomaa, 60.

${ }^{33}$ Ibid.
} 
Tribunal) included aggression among the three categories of crimes ${ }^{34}$ that should come within the jurisdiction of the Nuremberg Tribunal. It stipulated that:

... The following acts, or any of them, are crimes coming within the jurisdiction of the Tribunal for which there shall be individual responsibility:

(a) Crimes against peace: Namely, planning, preparation, initiation or waging of a war of aggression, or a war in violation in a common plan or conspiracy for the accomplishment of any of the foregoing. ${ }^{35}$

Brownlie found that the provisions on crimes against peace, as finally drafted, were the result of a compromise. The compromise was to make a charge of launching aggressive war alternative or additional to a charge of initiating war in violation of treaties, although if the reference to treaties, agreements, and assurances was a rehearsal of the sources of law then it was tautological. The result was a clumsy formula which in terms created the distinct offence consisting in violation of international treaties, agreements or assurances. ${ }^{36}$

The Charter of the International Military Tribunal for the Far East (hereafter Tokyo Tribunal) defined crimes against peace almost identically in article 5 on Jurisdiction over Persons and Offences. ${ }^{37}$ The only difference was the addition to the formula copied from Article VI of the Nuremberg Charter of the phrase "declared or undeclared" in respect of a war of aggression. It may have been intended by that addition to emphasize that aggressive war, in whatever disguise, was an international crime. ${ }^{38}$

Concerning article VI of the Charter, there are two notable issues to review in relation to the crime of aggression. First, this formulation attempted to define aggression by a mere reference to the element of 'participation.' The underlying idea of the article's scope ratione materiae involved the notion of participation, whether active or passive. ${ }^{39}$ It actually evades the issue of definition and did not coincide with the essential

\footnotetext{
34 They are 'Crimes against peace', 'War Crimes' and 'Crimes against Humanity.'

35 The two other crimes stipulated as "War Crimes" : namely, violations of the laws and customs of war and "Crimes against Humanity" : namely, murder, extermination, enslavement, deportation, and other inhumane acts committed against any civilian. Mohammed M. Gomaa, 61.

${ }^{36}$ Ian Brownlie, International Law and the Use of Force by States (Oxford: Clarendon Press, 1963 reprinted 1991) 163-164.

${ }^{37}$ Article 5 stipulated as follows:

"The following acts, or any of them, are crimes coming within the jurisdiction of the Tribunal for which there shall be individual responsibility:

(a) Crimes against peace: Namely, the planning, preparation, initiation or waging of a declared or undeclared war of aggression, or a war in violation of international law, treaties, agreements or assurances, or participation in a common plan or conspiracy for the accomplishment of any of the foregoing."

38 Mohammed M. Gomaa, 62.

39 Ibid, 61.
} 
characteristics of the crime of aggression as a leader crime which will be discussed in part II.2. A second issue is that article VI did not include a definition of aggression or a war of aggression or what constituted such concepts. The mere mention of 'a war of aggression' in paragraph (a) without any indication as to what it means beyond the provision that the planning, preparation, initiation or waging of it, or participation in a common plan or conspiracy for its accomplishment makes it a crime against peace for which there can be individual responsibility implies that the definition of "war of aggression" is to be found in instruments other than the Charter itself. ${ }^{40}$ To some extent, it is a weakness in the Nuremberg Charter as it fails to define war of aggression.

The charge of Crimes against Peace was a new international criminal concept which came out of the Nuremberg Charter and the Nuremberg judges expressed it as the "supreme international crime." While the definition of the crime of aggression or the concept of individual criminal responsibility was still not adopted in the Charter or its judgment, this became the beginning of the all afterward discussion and debates on the crime of aggression.

Based on the logic of the formula arrived at London Conference, the Nuremberg Tribunal proceeded to charge and judge the defendants in a manner that put into effect the link between the Charter which contained the crimes to be committed by the individual and the aggression which was to be found elsewhere. And on 11 December 1946, a few weeks after the conclusion of the Nuremberg tribunal, the U.N. General Assembly unanimously approved resolution $95(\mathrm{I})^{41}$, where such formula sanctioned by the Charter and by the decisions issued by the tribunal were confirmed and recognized as the international law principle - the criminality of a war of aggression. ${ }^{42}$ A few scholars argue that since the Nuremberg trials, this principle became customary international law through the U.N., the International Law Commission, and each national government. ${ }^{43}$

After the Nuremberg Tribunal, most legal work on the crime of aggression proceeded under the International

\footnotetext{
${ }^{40}$ Ibid.

41 Affirmation of the Principle of International Law recognized by the Charter of the Nuremberg Tribunal, G.A. Res. 95(I), U.N. GAOR, $1^{\text {st }}$ Session, 55 ${ }^{\text {th }}$ Plen. Mtg., (1946)

42 Umberto Leanza, "The Historical Background of the Crime of Aggression” 1. in The International Criminal Court and the Crime of Aggression, ed. Mauro Politi and Giuseppe Nesi (Ashgate, 2004)

${ }^{43}$ Theodor Meron, "Defining Aggression for the International Criminal Court", Suffolk Transnat'1 L. Rev.1, winter (2001), 6. 
Law Commission with the request of the U.N. General Assembly. ${ }^{44}$

\subsubsection{Work of the International Law Commission}

The International Law Commission's (hereafter ILC) drafts on State Responsibility and the Code of Crimes against the Peace and Security of Mankind ${ }^{45}$ both dealt with the regulation of the "crime of aggression": The former drafts as an international crime gave rise to international responsibility and the latter one as a crime against peace which gave rise to criminal responsibility of individuals. The ILC decided not to propose a general definition of crimes against the peace and security of mankind but left to practice to define the exact contours of the concept of crimes against peace as identified in article VI of the Charter of the Nuremberg Tribunal.

As stated above, the distinction between State responsibility and individual responsibility in connection with aggression was recognized and very well preserved in the work of the ILC. The Commission was seeking to define the crime of an individual who, in a case of aggression committed by a state, might be a leader or organizer of the crime and was personally liable for it. ILC also relied on the formula at the London Conference to prosecute individuals for aggression in the course of its characterization of aggression as an offence against the peace and security of mankind. ${ }^{46}$ The drafting of article 16 of the Code of Offenses Against the Peace and Security of Mankind provides that:

An individual who, as leader or organizer, actively participates in or orders the planning, preparation, initiation or waging of aggression committed by a State shall be responsible for a crime of aggression. ${ }^{478}$

${ }^{44}$ G.A. Res. 177(II), U.N. GAOR, $2^{\text {ND }}$ Session, U.N. Doc. A/519 (1947)

45 U.N. GAOR, $51^{\text {ST }}$ Session. Supp. No. 10. U.N. Doc. A51/10 (1996) The ILC had considered the draft articles adopted by the Drafting Committee on second reading at its $2437^{\text {th }}$ to $2454^{\text {th }}$ meetings from 6 June to 5 July 1996 and adopted the final text of a set of 20 draft articles constituting the code. Mohammed M. Gomaa, 63.

46 At the $48^{\text {th }}$ session, the Drafting Committee had continued its work on the basis of two ideas: first, it had taken the view that a clear distinction had to be drawn between the definition of aggression committed by a state, on the on hand, and the crime of aggression committed by an individual on the other. A majority of the members of the Drafting Committee had felt it unnecessary for the Commission to attempt to define aggression, which was covered in the Charter and defined by the General Assembly, especially as individuals, and not States, were the subject of the Code. Summary records of the meetings of the $48^{\text {th }}$ session, 60 quoted in Mohammed M. Gomaa, 63.

47 ILC, Draft Code of Offences against the Peace and Security of Mankind, in YBILC vol. II (2) (1996) Art. 16.

48 'Leaders' or 'Organizers', an expression that was taken from the Charter of the Nuremberg Tribunal, must be understood in the broad sense, that is to say, as referring, in addition to the members of a Government, to persons occupying high-level posts in the military, the diplomatic corps, political parties and industry, as recognized by the Nuremberg Tribunal that: "Hitler could not 
The phrase "an individual ... shall be responsible for a crime of aggression" indicates that the scope of the article is limited to the crime of aggression for the purpose of individual criminal responsibility, where an individual, as leader or organizer, participates in that aggression. At the same time, it refers to "aggression committed by a State." Thus, it does not address the question of the definition of aggression by a state which is beyond the scope of the Code. During 1954 and 1996, ILC submitted three drafts of the Code but none were adopted by the U.N. The internationally agreed definition of aggression was only reached in 1974 in the General Assembly of the U.N. ${ }^{49}$

\subsubsection{The General Assembly Resolution 3314(XXIX) of 1974 on the Definition of Aggression}

After the Nuremberg trial, there had been a few outbreaks which can be recognized as 'war of aggression.' However, the Security Council has been extremely reluctant to find that there has been an act of aggression; it has done so only with regard to actions by Israel, South Africa, and Rhodesia. ${ }^{50}$ Thus, many member states argued to the General Assembly the necessity to make an instrument to decide and confirm the act of aggression, and by the resolution $378 \mathrm{~B}(\mathrm{~V})$ of 17 November 1950, the General Assembly asked the ILC to define aggression and to establish special committees to that ends. ${ }^{51}$

Consequently, several Special Committees on the Question of Defining Aggression were set up by the General Assembly resolutions from 1952 to $1965 .^{52}$ However, no definition was approved in spite of numerous efforts.

make aggressive war by himself. He had to have the cooperation of statesmen, military leaders, diplomats and businessmen." Ibid, Commentary to Art. 16, 43.

49 Mohammed M. Gomaa, 64.

50 Christine Gray, International Law and the Use of Force (Oxford University Press, 2000) 196-199. The General Assembly has been ready to denounce acts of aggression; but such resolutions were usually discounted by permanent members as not authoritative finding under Chapter VII.

51 Mohammed M. Gomaa, 70.

52 The first Special Committee on the Question of Defining Aggression was set up by the General Assembly resolution 688(VII) of 20 December 1952. It was composed of fifteen members. It lasted from 1953 to 1954. U.N.Doc. A/RES/688(VII), U.N. GAOR. Suppl. 20(A/2361), para.5(a)(b) (1952); U.N. Doc. A/2638 (1953); The second Special Committee established in accordance with resolution 895(IX) of 4 December, 1954, remained in force between 1956 and 1957. This Committee consisted of nineteen members. U.N. Doc. A/3574 (1956); The third one, consisting of twenty one members, was established under resolution 1181(XII) of 29 November, 1957, and continued from 1959 to 1967. U.N. Doc. A/AC.91/2 (1959); U.N.Doc. A/AC.91/3 (1962); U.N. Doc. A/AC.91/5 (1965) 
Finally, in 1967, the General Assembly resolution 2330 (XXII) of 18 December 1967 entitled "Need to expedite the drafting of a definition of aggression in the light of the present international situation" was adopted, and through this resolution, the General Assembly established fourth but last Special Committee consisting of thirty five members. It should be pointed out that in this resolution the General Assembly noted that "there was still at that date (in 1967) no generally recognized definition of aggression." ${ }^{.53}$ In other words, it confirmed that the definition contained in article VI of the Nuremberg Charter was not in itself conceived as a definition of aggression. ${ }^{54}$

The fourth Special Committee was successful in drafting the definition annexed to General Assembly resolution $3314\left(\right.$ XXIX) $^{55}$ of 14 , December, 1974. At last, it became the generally recognized definition of aggression, but it took almost 20 years to adopt the definition of aggression after making Special Committee in 1952.

Concerning the resolution 3314(XXIX) of 1974, there have been constant debates on the issues of the legal content and customary nature of the Definition of Aggression in it.

The "Definition of Aggression" annexed to resolution 3314(XXIX) of 1974 employed two approaches at the same time: a deductive approach in article $1^{56}$ in which it proposed a general formula like the article 2 paragraph 4 of the Charter of the United Nations; an inductive approach in which it enumerated acts which constitute aggression in a non-exhaustive manner as appears in article $3 .^{57}$

${ }^{53}$ U.N. Doc. A/C.6/L/644 (1967)

${ }^{54}$ Umberto Leanza, 5-6.

${ }^{55}$ G.A. Res. 3314(XXIX), U.N. GAOR $6^{\text {th }}$ Comm., $29^{\text {th }}$ Session, $2319^{\text {th }}$ plen. mtg. (1974)

${ }^{56}$ Article 1 states:

"Aggression is the use of armed force by a State against the sovereignty, territorial integrity or political independence of another State, or in any other manner inconsistent with the Charter of the United Nations, as set out in this Definition."

${ }^{57}$ Article 3 states:

"Any of the following acts, regardless of a declaration of war, shall, subject to and in accordance with the provisions of article 2, qualify as an act of aggression:

(a) The invasion or attack by the armed forces of a State of the territory of another State or any military occupation, however temporary, resulting from such invasion or attack, or any annexation by the use of force of the territory of another State or part thereof;

(b) Bombardment by the armed forces of a State against the territory of another State or the use of any weapons by a State against the territory of another State;

(c) The blockade of the ports or coasts of a State by the armed forces of another State;

(d) An attack by the armed forces of a State on the land, sea or air forces, or marine and air fleets of another State;

(e) The use of armed forces of one State which are within the territory of another State with the agreement of the receiving State, in contravention of the conditions provided for in the agreement or any extension of their presence in such territory beyond the termination of the agreement; 
Resolution 3314 deals with aggression by States, not with the crimes of individuals. As such, and without the appropriate reference to the act of the individual, it is of no use whatsoever for the purposes of criminal law. ${ }^{58}$ Especially, article 5 paragraph 2 clearly distinguishes "war of aggression" from "aggression"59 to classify individual criminal responsibility and state responsibility. The differences of the terms employed will be helpful to apply this definition to that of ICC and also to define the proper one of the crime of aggression. ${ }^{60}$

As to the significance and value of the Definition of Aggression annexed to resolution 3314, it has been argued by some member states of the ICC that the International Court of Justice (hereafter ICJ) did not consider that definition as a customary international law, but only article 3 , as reflective of customary international law ${ }^{61}$ in its judgment in 1986 in the case concerning Military and Paramilitary Activities in and against Nicaragua. ${ }^{62}$ ICJ explicitly pointed out sub-paragraph (g) of article 3 as a reflection of such custom. ${ }^{63}$ In considering whether the sending by or on behalf of a State of armed bands, groups, irregulars or mercenaries which carry out acts of armed force against another State, amounted to aggression, the ICJ relied on sub-paragraph (g) to prove that it actually so amounted. In the view of the ICJ, the rule contained in sub-paragraph (g) was already in 1986 of a customary value. ${ }^{64}$ Therefore, the ICJ intended to emphasize the customary nature of this problematic provision in that subparagraph, while other provisions in the resolution were universally accepted as customary international law. This was not to say that only that sub-paragraph reflected custom. In other words, the ICJ, by referring to that particular sub-paragraph wanted to say that it had the same status as the other sub-paragraphs which were already reflective of custom.

Thus, it is desirable to recognize the customary nature of the "Definition of Aggression" annexed to

(f) The action of a State in allowing its territory, which it has placed at the disposal of another State, to be used by that other State for perpetrating an act of aggression against a third State;

(g) The sending by or on behalf of a State of armed bands, groups, irregulars or mercenaries, which carry out acts of armed force against another State of such gravity as to amount to the acts listed above, or its substantial involvement therein."

${ }_{58}^{58}$ Mohammed M. Gomaa, 73.

${ }^{59}$ Article 5 paragraph 2 states:

"(2) A war of aggression is a crime against international peace. Aggression gives rise to international responsibility."

${ }^{60}$ Phani Dascalopoulou-Livada, "Aggression and the ICC: Views on Certain Ideas and their Potential for a solution" 83 in The International Criminal Court and the Crime of Aggression, ed. Mauro Politi and Giuseppe Nesi (Ashgate, 2004)

61 Mohammed M. Gomaa, 73.

${ }^{62}$ Military and Paramilitary Activities in and against Nicaragua (Nicaragua v. United States of America), Merits, Judgment of 27, June 1986 (ICJ Reports, 1986) 14.

${ }^{63}$ Ibid, para.195, 103

${ }^{64}$ Mohammed M. Gomaa, 74. 
resolution 3314, even though it has been generally considered that the resolution adopted by the General Assembly has no legal binding force.

\subsubsection{After the Rome Conference}

The history to define the crimes of aggression for the last century shows how hard work it is to accomplish the end. Meanwhile, it is undeniable that such considerable efforts have strengthened the understanding of the crime of aggression and the necessity to punish this crime. The work to define the crimes of aggression has continued after the establishment of the ICC under the Rome Statute.

Under article 5 of the Rome Statute and the Final Act of the Rome Conference, there have been ten sessions of the Preparatory Commission (hereafter PrepCom) from February 1999 to July $2002 .{ }^{65}$ The discussion within the PrepCom went through three phases.

The first phase went from the beginning of the work of the PrepCom in February 1999 until the end of the second session in August 1999. It is characterized by a focus on procedural arguments and maneuvers to establish the ICC. ${ }^{66}$ No significant progress was made, but during this phase there was an agreement to produce a compilation of all the various proposals related to aggression.

The second phase covers the three sessions of the PrepCom from December 1999 until 30 June 2000, and during this phase, both the rules of procedure and the elements of crimes were finalized. ${ }^{67}$ Various proposals for the definition of the crimes of aggression submitted by member states and those were arranged and organized in certain categories.

The last phase went from June 2000 to July $2002{ }^{68}$ As the other documents had been finalized, the interest of a great number of states turned to the question of aggression, and the participation in the discussion were

\footnotetext{
${ }^{65}$ Mauro Politi, "The Debate within the Preparatory Commission for the International Criminal Court", 44 in The International Criminal Court and the Crime of Aggression, ed. Mauro Politi and Giuseppe Nesi (Ashgate, 2004)

${ }^{66}$ Ibid.

${ }^{67} \mathrm{Ibid}, 45$.

${ }^{68}$ Ibid.
} 
considerably increased.

After the Rome Statute entering into force on 1 July 2002, the Assembly of States Parties to the Rome Statute decided to establish 'Special Working Group on the Crime of Aggression'. Until now, there have been four sessions of this working group. ${ }^{69}$ More details in its discussion will be reviewed in part III on definition of the Crime of Aggression.

\subsection{The Essential Characteristics of the Crime of Aggression}

The Crimes of Aggression has some different characteristics compared with other crimes $^{70}$ in the Rome Statute. These essential characteristics are also important to define the crime of aggression, because these characteristics are the core parts of the definition and the conditions for the jurisdiction of this crime. Four essential characteristics of the crime of aggression will be discussed.

\subsubsection{The Act of Aggression and the Crime of Aggression}

Aggression has particular features which distinguish it from the other crimes under the Rome Statute. It is not a crime committed by individuals. It is an unlawful act which can only be committed by a collectivity. In other words, act by the State must be preceded. Therefore, aggression itself cannot be entertained directly by the ICC as it does not pertain ratione personae to individuals who come under its jurisdiction. ${ }^{71}$

We can not speak about crime of aggression in the absence of an act of aggression. Dealing with states' responsibility is not possible for the ICC according to the Statute not even in the case of aggression. ${ }^{72}$ This is why

\footnotetext{
69 Sang-Hyun Song, "The Rome Statute and the International Criminal Court - Challenges and Opportunities" SNU Law Journal 44, 3 (2003): 260

70 They are "the crime of genocide", "war crimes" and "crimes against humanity" which are stipulated in article 5 paragraph 1 of the Rome Statute.

71 Ioana Gabriela Stancu, "Defining the Crime of Aggression of Redefining Aggression?" 88 in The International Criminal Court and the Crime of Aggression, ed. Mauro Politi and Giuseppe Nesi (Ashgate, 2004)

72 Ibid, 89.
} 
some states argue that the ICC should refrain from making any determination, either directly or indirectly, of the existence of aggression concerning the matter of jurisdiction.

The attempt to divide these two concepts -state responsibility and individual criminal responsibility- can be found in article 16 of the Draft Code of Offences against the Peace and Security of Mankind which referred to "aggression committed by a State." 73 There is an inevitable link between the international responsibility of the state for aggression and individual criminal responsibility for crimes of aggression. Thus, only after a State has been declared as an aggressor, for example pursuant to the Charter of United Nations and the definition of aggression annexed to General Assembly resolution 3314, can an individual be tried on the basis of this legal nexus for the purposes of individual criminal responsibility and furthermore, the Rome Statute. ${ }^{74}$

Concerning the crime of aggression, the question is whether the act of aggression that reaches to the extent of individual criminal responsibility, identical with the act of aggression which generally raises state responsibility.

As stated in part II.1 on historical background, only the term "war of aggression" was used in the Nuremberg Charter and the Resolution 3314(XXIX) of $1974^{75}$ that referred to the crime of aggression. Thus, as far as international customary law is concerned, it is only a "war of aggression" which constitutes the crime of aggression in international law. ${ }^{76}$ The consequence of this is that there may be a violation by a state of an international law rule against the use of force which does not give rise to individual criminal culpability for the crime of aggression. ${ }^{77}$

Some scholars and a few states proposed that by using terms like "serious" or "massive," the act of aggression committed by a state can be distinguished from the crime of aggression committed by an individual. However, the jurisdiction of the Court is already limited by article 5 paragraph 1 of the Rome Statute ${ }^{78}$ to the most

\footnotetext{
73 ILC, Draft Code of Offences against the Peace and Security of Mankind, in YBILC vol. II (2) (1996) Art. 16; Mohammed M. Gomaa, 65.

74 Ioana Gabriela Stancu, 89.

75 Only exception can be the article 5 paragraph 2 of the resolution 3314(XXIX). This provision clearly distinguishes "war of aggression" from "aggression" to classify individual criminal responsibility and state responsibility. It states that "a war of aggression is a crime against international peace. Aggression gives rise to international responsibility."

${ }^{76}$ Elizabeth Wilmshurst, "Definition of the crime of aggression: state responsibility or individual criminal responsibility?" 95 in The International Criminal Court and the Crime of Aggression, ed. Mauro Politi and Giuseppe Nesi (Ashgate, 2004)

77 Ibid.

78 Art.5.1 states that:

“ 1 . The jurisdiction of the Court shall be limited to the most serious crimes of concern to the international community as a whole.
} 
serious crimes of interest to the international community as whole. New formulations that can cover this essential element of the crime of aggression should be designed. ${ }^{79}$

Lately, from this perspective, many proposals were presented on the definition of the crime of aggression which tried to make a clear-cut distinction between the concept of the crime of aggression and the concept of aggression by a State. ${ }^{80}$ Such proposals contained two paragraphs: one defining the act of aggression and the other defining the crime, both for the purposes of the Rome Statute. These proposals were welcomed by many member states as an important step forward, at least from a methodological point of view. ${ }^{81}$

\subsubsection{Leadership Crime}

There seems to be an agreement that at least the crime of aggression is a leadership crime. ${ }^{82}$ In other words, it is a crime to be restricted to acts committed by state officials, particularly by those individuals in a position of political or military leadership or who are otherwise the organizers or planners of acts constituting aggression. ${ }^{83}$ Thus aggression is a crime perpetrated by those who have decision-making power on behalf of a state.

It is not a crime that can be committed by people acting in a private capacity, or by low-level political or military officials of a State. This is a point of agreement among the various proposals from the PrepCom, which is

The Court has jurisdiction in accordance with this Statute with respect to the following crimes:

(a) The crime of genocide;

(b) Crimes against humanity;

(c) War crimes;

(d) The crime of aggression.

79 Elizabeth Wilmshurst, 96.

${ }^{80}$ Proposal submitted by Bosnia and Herzegovina, New Zealand and Rumania, Definition of the crime of aggression, U.N. Doc. PCNICC/2001/WGCA/DP.2 (2001); Proposal submitted by Cuba, Definition of the crime of aggression and conditions for the exercise of jurisdiction, U.N. Doc. ICC-ASP/1/L.4 (2003)

81 Silvia A. Fernandez de Gurmendi, "The working group on aggression at the preparatory commission for the international criminal court", 25 Fordham Int'l L.J. 589, (2002) 597.; Giuseppe Nesi, "An Outsider's View" 167 168 in The International Criminal Court and the Crime of Aggression, ed. Mauro Politi and Giuseppe Nesi (Ashgate, 2004)

${ }^{82}$ Hans-Peter Kaul, "The crime of aggression: Definitional options for the way forward", 101 in The International Criminal Court and the Crime of Aggression, ed. Mauro Politi and Giuseppe Nesi, (Ashgate, 2004); Third Session, Special Working Group on the Crime of Aggression, U.N. Doc. ICC=ASP/3/SWGCA/INF.1 (2004) 9; Fourth Session, Special Working Group on the Crime of Aggression, U.N. Doc. ICC-ASP/4/SWGCA/INF.1, (2005) 7 8, 10; Mauro Politi, 46.

${ }^{83}$ Mauro Politi, 47. 
duly reflected in the consolidated text. ${ }^{84}$

However there is a potential shortcoming because of the leadership characteristic of the crime of aggression. The acts of aggression committed by individuals who are not officially affiliated with a state entity can not be subject to the jurisdiction of the ICC. Thus, terrorists and revolutionary groups could possibly plan, initiate, and wage aggressive war with impunity. ${ }^{85}$ Some scholars even argue that any deterrent effect of the ICC will not apply to the individual members of these non-state groups because they need not fear prosecution by the ICC. ${ }^{86}$

Though everybody seems to agree that the crime of aggression is a leadership crime, the question of how to define the act or the conduct of the leader still remains a difficult problem. Most proposals submitted to PrepCom have chosen the definition from the Nuremberg Tribunal. For example, the Russian proposal ${ }^{87}$ which is also supported by France, and the former German proposal ${ }^{88}$ draw on the precedent of the Nuremberg Tribunal. They characterize the conduct in question with the notions "to initiate, carry out, plan, prepare or order an armed attack." But, there are other proposals that more or less renounce a concretization of the individual act or contribution of the leader in question and as a result do not provide such provisions. ${ }^{89}$

Therefore, a list of the category of persons involved should be agreed upon to satisfy "the principle of legality." Individuals need to know ex ante whether they actually belong to a category of persons that could be individually responsible of the crime of aggression. It could be very difficult to draw the line between policy makers and mere executioners, in particular in a democratic society where a large number of persons belonging to different agencies of the executive and parliament or other economic sectors of a state, could be involved in preparing and shaping a decision. ${ }^{90}$

After the discussions during the tenth PrepCom session, the Coordinator of the working group on the crime of aggression made a certain guideline for the definition and jurisdiction of this crime, which is called a 'discussion

\footnotetext{
${ }^{84}$ Hans-Peter Kaul, 101.

85 Tae-Hyun Choi, 221.

${ }^{86}$ Grant M. Dawson, "Defining substantive crimes within the subject matter jurisdiction of the international criminal court: what is the crime of aggression?" 19 N.Y.L.Sch. J.Int'1 \& Comp. L. 413, (2000) 444

${ }^{87}$ Proposal submitted by the Russian Federation: definition of the crime of aggression U.N. Doc. PCNICC/1999/DP.12 (1999)

${ }^{88}$ Proposal submitted by Germany: definition of the crime of aggression U.N. Doc. PCNICC/1999/DP.13 (1999)

${ }^{89}$ Hans-Peter Kaul, 103.

90 Silvia A. Fernandez de Gurmendi, 598.
} 
paper" $^{91}$.' It stipulates in article 3 that "[t]he provisions of articles 25 paragraphs 3, 28 and 33 of the Statute ${ }^{92}$ do not apply to the crime of aggression" and its nature as a leadership crime. But in the Special Working Group ${ }^{93}$ on the crime of aggression which was established after the effectuation of the Rome Statute, there is a strong argument to exclude the article 3 of the "discussion paper." ${ }^{94}$ The general principles of criminal law should be still applicable to the crime of aggression, even though it is a leadership crime. ${ }^{95}$

In addition, the scope of application to the article 27 of the Rome Statute on "irrelevance of official capacity" should be limited, since people like low-level political or military officials of a state can not be responsible for this crime as commented earlier. Thus, such limitation should be applied to this crime and it is more appropriate to include this limitation in the provision of the definition of the crime of aggression. ${ }^{96}$

\subsubsection{Manifest violation of the Charter of the United Nations}

Another essential characteristic of the crime of aggression is that the use of armed force or the armed attack as an element of this crime must be in manifest contravention or violation of the Charter of the United Nations (hereafter UN Charter). It must coincide with the article 5 paragraph 2 of the Rome Statute which stipulates that

\footnotetext{
91 Discussion paper proposed by the Coordinator, U.N. Doc. PCNICC/2002/WGCA/RT.1 /Rev.1, (2002); This discussion paper received little support from the majority of PrepCom delegates. Their main concern was that the various proposals had been oversimplified since they felt that the proposed options for the crime of aggression could not be reconciled. The same could be said for the determination of the conditions for the exercise of jurisdiction over an act of aggression. In other words, in an attempt to find a common ground, the text paradoxically ascertained the enormous distances between the various proposals thus far presented. Especially, according to many delegates it was strongly blamed why the definition of the act of aggression, taken from General Assembly Resolution 3314(XXIX) of 1974, had to be subject to a prior determination by the United Nations Security Council. Even, through informal proposals Samoa, France Cameroon, and the Netherlands expressed that discussion paper made the debate on the crime of aggression during the tenth PrepCom session fruitless, leaving the impression that no progress has been made over time and the discussions were back to where they started.; Giuseppe Nesi, 170.

92 Article 25 of the Rome Statute is about "individual criminal responsibility," and article 28, about "responsibility of commanders and other superiors."

93 A Special Working Group on the crime of aggression opens on an equal footing to all U.N. member States, members of specialized agencies and the International Atomic Agency to draft proposals for a provision on aggression.; Giuseppe Nesi, 172.

${ }^{94}$ First Session (First and Second Resumptions) Draft Report of the Assembly of States Parties to the Rome Statute of the International Criminal Court, U.N. Doc. ICC-ASP/1/L.5 (2003)

95 The more details will be discussed in part III.

${ }^{96}$ Irina Kaye Muller-Schieke, "Defining the Crime of Aggression under the Statute of the International Criminal Court", 14 Leiden J. of Int'l 409 (2001) 420.
} 
"such a provision shall be consistent with the relevant provisions of the Charter of the United Nations." parts of the proposal submitted to the PrepCom used the formulation like "in manifest violation of the Charter of the United Nations" as a definitional element. ${ }^{98}$

But to be a manifest violation of the UN Charter, the quantity and intensity of the use of armed force or armed attack and the quality and gravity of the injurious consequences still remain very controversial and unresolved. Related with this issue, delegates in the PrepCom and in the Special Working Group on the crime of aggression have used the new formula, so called "threshold issue." 99 This new phrase is now more and more familiar and frequently used by delegates in the ICC. ${ }^{100}$

For example, the German proposal ${ }^{101}$ submitted to the PrepCom takes as a point of departure the notion of "armed attack" as referred to in article 51 of the UN Charter. It then stipulates that the armed attack in question must result in an "occupation or annexation." Regardless whether this proposal is a proper definition or not, it is notable that an aggressive, large-scale armed attack committed by a state on the territorial integrity of another state, clearly without justification under international law, represents indeed the very essence of this crime. ${ }^{102}$ However, even though there is an agreement on "threshold issue," it just settles the problem on act of aggression by state and does not mean an agreement on the definition for individual criminal responsibility, as stated above in part 2.2.1.

In short, the definition of the crime of aggression can not be derived without a clear, precise and well-defined definition which deals with the quality, quantity, dimension, intensity, grave consequences or overall gravity of the armed attack as a manifest violation of the UN Charter. ${ }^{103}$

\subsubsection{Compliance with the Principle of legality}

\footnotetext{
97 Hans-Peter Kaul, 101.

98 Proposal submitted by Greece and Portugal, U.N. Doc. PCNICC/1999/WGCA/DP.1 (1999)

99 Hans-Peter Kaul, 102.

100 Ibid.

101 Proposal submitted by Germany: the crime of aggression -a further informal discussion paper, U.N. Doc. PCNICC/2000/WGCA/DP.4 (2000)

102 Hans-Peter Kaul, 103.

103 Ibid.
} 
The definition of the crime of aggression should meet the principle of legality. Some scholars argue that to comply with the principle of legality requires that the crime's definition reflect customary law. ${ }^{104}$ Questions have been raised in the PrepCom about the use of customary law as one of the benchmarks for considering the various proposals for a crime of aggression. Some delegations suggested that article 7 on crimes against humanity and article 8 on war crimes of the Rome Statute already went beyond customary law, and accordingly they argued that the PrepCom could legislate rather than codify the definition of the crime of aggression. ${ }^{105}$

However, there has been a strong support for the definition of aggression resting on strong foundation of customary law. An objective analysis indicates those articles 6 to 8 of the Rome Statute are in general conformity with customary law. ${ }^{106}$ Delegations filled in some gaps in the Rome Conference, but this took place only on the margins of precisely described crimes against humanity and war crimes. ${ }^{107}$

In the area of crimes against humanity and war crimes, there has been some jurisprudence since Nuremberg. ${ }^{108}$ Certain articles on crimes contained in the Statutes of the ad hoc Tribunals for the former Yugoslavia (hereafter ICTY) and Rwanda (hereafter ICTR) were considered as declaratory of customary law ${ }^{109}$ and also provide guidance for the crimes in article 6 to 8 of the Rome Statute. In addition, there were the ICTY and ICTR decisions defining various aspects of international humanitarian law, especially regarding non-international armed conflicts, as customary rules whose violation involved the individual criminal responsibility of the perpetrators. ${ }^{110}$

In short, a more firm foundation of customary law existed than the definition of the crime of aggression as shaped by the UN Charter and the jurisprudence of the Nuremberg Tribunal. Unless customary law is followed and the crime is clearly defined to meet the requirements of criminal justice, the principles of legality can not be observed. Therefore, the concept of customary law should be taken seriously. In other words, it must mean

104 Theodor Meron, 7.

105 Tae-Hyun Choi, 218.

106 Theodor Meron, War Crimes Law Comes of Age (London: Oxford Press, 1998) 305-317 quoted in Theodor Meron, 8.

107 Ibid.

108 Tae-Hyun Choi, 218: in this article, author illustrates a few cases like: Touvier case (Cour de Cassation, France) 27 November 1992, Bull. Crim, 394 (1992), Barbie case (Cour de Cassation, France) reproduced in International Law Report, vol. 78 (1990) 125 and Eichmann case (District Court, Israel) reproduced in International Law Report, vol. 36 (1968) 18.

109 Report of the Security Council to Secretary-General, U.N. GAOR, U.N. Doc. S/25704 (1993); Theodor Meron, 9.

110 Prosecutor v. Tadic, Decision on the Defence Motion for Interlocutory Appeal on Jurisdiction, 2, October, 1995, IT-94-1AR72 (1995); Tae-Hyun Choi, 218. 
something more than what one state or delegation group wants it to be. Customary law should not be ideology, but a reflection of both widespread practice and the general opinio juris of states. ${ }^{111}$

With respect to resolution 3314(XXIX) of 1974, it is doubtful that the resolution states customary norms of international criminal law for the crime of aggression. At the time of its adoption, the resolution did not restate already existing customary law as stated in part 2.1.5. Surely as many scholars argued, this resolution has hardened in to customary law. However, the ICJ has stated that the resolution must meet two requirements to become customary law. The resolution must have concordant settled practice and opinio juris generalis. As stated in the North Sea Continental Shelf cases, one has to demonstrate a settled practice and evidence of a belief that the practice is rendered obligatory by the existence of a rule of law. ${ }^{112}$ In the judgment of the Nicaragua case, existence of a rule in the opinion juris of states must be confirmed by practice. ${ }^{113}$ Obviously, there has been no concordant practice based on Resolution 3314(XXIX) of 1974.

To create and define a new crime of aggression under the Rome Statute and follow a legislative approach would give a chance to member States and individuals to contest the ICC's legitimacy in the future. This should be avoided by basing the work to define the crime of aggression on the firm foundations of customary law. ${ }^{114}$ Thus, the Special Working Group on the Crime of Aggression should discuss and determine how to build such a foundation based upon customary.

\footnotetext{
111 Tae-Hyun Choi, 219.

112 North Sea Continental Shelf, Merits, para.77. (ICJ Reports 1969), 44.

113 Military and Paramilitary Activities in and against Nicaragua (Nicaragua v. United States of America), Merits, para. 184. (ICJ Reports, 1986) 98.

114 Theodor Meron, 12.
} 


\section{Definition of the Crime of Aggression}

This chapter argues that first the definition of this crime should follow the "generic approach." Second, the crime of aggression and the act of aggression should be separately stipulated in the definition. That is, the crime of aggression should contain the provisions included in the Nuremberg Charter and also reflect the general recognition on it developed up the point of current circumstances. The act of aggression should follow the provisions of precedents such as resolution 3314(XXIX) of 1974 and the ILC Draft Code of Crimes against the Peace and Security of Mankind 1996. Third, the definition of the crime of aggression should comply with the principle of legality. Thus essential material and mental elements of crime should be included in it

\subsection{Generic approach and List approach}

There have been mainly two approaches concerning the definition of the crime of aggression. The first one is the "generic approach" that proposes a general or abstract definition and the second one is the "list approach" that enumerates the specific acts constituting aggression.

Under the generic approach, there is a proposal that follows the Nuremberg Charter closely in which it criminalizes a "war of aggression." 115 Its supporters underline the importance of the Nuremberg Charter, which they consider to be the only authoritative text in international law, being the only one that established and actually recognized individual criminal responsibility.

However, there is an argument against the definition contained in the Nuremberg Charter is that the concept of "war of aggression" relates to post war and does not apply to most forms of contemporary violence. ${ }^{116}$ Furthermore, there have been objections that this definition is a circular one that can hardly satisfy today's more

115 Consolidated Text of Proposals on the crime of aggression prepared by the Coordinator, Proceedings of the Preparatory Commission, ninth session (hereafter Consolidated Text by Coordinator), Option2, 14. U.N.Doc. PCNICC/2002/L.A/Rev.1 (2002); The Proposal incorporated in the Consolidated Text of Proposals on the crime of aggression prepared by the coordinator as Option 2 is the closest one to the Nuremberg Charter.; It states:

"For the purposes of the present Statute and subject to a prior determination by the United Nations Security Council of an act of aggression by the State concerned, the crime of aggression means any of the following acts: planning, preparing, initiating, carrying out a war of aggression."

116 Silvia A. Fernandez de Gurmendi, 596. 
strict standards of legality. ${ }^{117}$

As a result, within the same generic approach, other proposals contemplate definitions that draw their foundation from article 1 of the resolution 3314(XXIX) of 1974 and article 2 paragraphs 4 of the UN Charter to expand the concept of the definition to other types of illegal uses of force. ${ }^{118}$

Opposing or supplementing the generic approach, other delegations insist on the need of having a definition that would enumerate the list of acts constituting aggression. ${ }^{119}$ It is so called the "list approach." They claim that list should be based on the one contained in resolution 3314(XXIX) of 1974 which was adopted by consensus after many years of extensive negotiations in the ILC and reflect customary international law. Also they argue that the list approach is consistent with other crimes of the Rome Statute, since these crimes are all stipulated by the list approach. $^{120}$

Those who object to the list approach argue that this resolution was not aimed at crimes of individuals, but at acts of states. Moreover, they claim that this is demonstrated not only by the legislative history as stated in part 2.2, but also by the text of the resolution itself, including article 5 paragraphs 2 of this resolution, which draws a distinction between the war of aggression qualified as a "crime against international peace" and the act of aggression which "gives rise to international responsibility."

Moreover, some scholars insist that the elements in article 3 of the resolution 3314 are just criteria to determine whether certain acts by a state can be considered aggression for the Security Council and after that, the ICC can determine whether the individuals responsible for the state's aggressive behavior are subject to personal and individual liability based on the principles of the Nuremberg Charter under the assumption that a state can act only

117 Ibid.
118 Consolidated Text by Coordinator, Option1, 13. U.N.Doc. PCNICC/2002/L. A/Rev.1 (2002); It states:

"For the purposes of the present Statute and subject to the determination of the Security Council regarding the act of a State, the crime of aggression means the use of armed force, including the initiation thereof, by an individual who is in a position of exercising control or directing the political or military action of a State, against the sovereignty, territorial integrity or political independence of a State in violation of the Charter of the United Nations."

119 Consolidated Text by Coordinator, Option1, Variation 3, 14. U.N.Doc. PCNICC/2002/L.A/Rev.1 (2002)

${ }^{120}$ Rome Statute of the International Criminal Court, art.6 on Genocide, art.7 on Crimes against Humanity, art. 8 on War crimes, U.N. Doc. A/CONF.183/9

121 See note 59. 
through its people. ${ }^{122}$

Also, some other scholars argue that the contents in the list on article 3 of the resolution 3314(XXIX) of 1974 reflected not the core element of the customary international law, but just the political situation at that time. ${ }^{123}$

In addition, as pointed out from the proposal of the Greece and Portugal, the list approach is not suited for the purposes of attributing criminal responsibility to individuals owing to the generally recognized principles of legality. The list approach would entail a protracted negotiation on whether a very extensive variety of acts should be included or not and on the particular elements of each such act. ${ }^{124}$

During the discussions at the PrepCom, the possibility of combining these two approaches in a single definition has been proposed. It would contain both an introductory paragraph of a general nature followed by a list of specific acts that constitute the offense. ${ }^{125}$ However, it seems that such an approach still would not in itself constitute a sufficient response to the defects of both generic and list part.

This paper argues that the definition of the crime of aggression should follow the "generic" approach. In accordance with the principle of legality, the "generic" approach can clearly prescribe the definition in a concise and general way. Also it allows the ICC to have its own discretion to determine the criminality in question, which can be an advantage as the crime of aggression has more of a political nature compared with other crimes of the Rome Statute.

The usefulness of the list contained in General Assembly resolution 3314 can not be denied. However, the list contained in that resolution being illustrative, it would, presumably, not encompass the variety of situations or acts of the present time. The definition of the crime of aggression should reflect the changes that have taken place in the last 50 years in international law and the changes that will occur in times to come. Therefore, the "generic" approach is a preferred choice to satisfy all these conditions.

122 Grant M. Dawson, 444-445.

123 Irina Kaye Muller-Schieke, 415.

124 Proposal submitted by Greece and Portugal, U.N. Doc. PCNICC/1999/WGCA/DP.1 (1999)

125 Silvia A. Fernandez de Gurmendi, 596. 


\subsection{Threshold of the Crime of Aggression and the Customary International Law}

Despite the fundamental disagreement among delegations surrounding the definition, all have recognized that to fall under the definition of aggression, the use of force should be of a certain magnitude or gravity. Uses of force of lesser intensity that occur, sometimes quite frequently, such as border skirmishes, cross-border artillery, armed incursions, and similar situations should not fall under the definition of aggression. ${ }^{126}$

Furthermore, acts of force of lesser gravity would not fall within the jurisdiction of the ICC, which only applies to the "most serious crimes of concern to the international community as a whole." ${ }^{127}$ Consequently, delegations have increasingly focused on this "threshold issue"128 or, in other words, the scale, magnitude, or gravity required for an act of use of force to amount to aggression.

In this respect, some formulations have been proposed. Some delegations suggested that the threshold requirement can be created by qualifying the violation of the norm, for example, use of force as a "manifest" violation of the U.N. Charter. ${ }^{129}$ Others suggest qualifying the acts by their consequences or goals like only acts of force that has as their object, or the result in, an annexation or occupation of territories. Finally, some delegations refer back to the Nuremberg Charter, arguing that the "war of aggression" has a threshold built in the concept that indicates the scale of violence that is required. ${ }^{130}$

The legislative history of the definitions of other crimes within the jurisdiction of the Court demonstrates the fundamental importance of finding the right "threshold" in order to reach agreement, and it is instrumental to the definition of aggression as well. ${ }^{131}$

Along with this "threshold issue," there is one more preceding issue to define the crime of aggression. As stated in part 2.2.4, we had a more recent and firm foundation of customary law than we have for the definition of

${ }^{126}$ Silvia A. Fernandez de Gurmendi, 597.

127 Art.5 para.1, Rome Statute of the International Criminal Court, U.N. Doc. A/CONF.183/9

${ }^{128}$ Hans-Peter Kaul, 102.

${ }^{129}$ See part 2.2.3. on Manifest violation of the Charter of the United Nations

${ }^{130}$ Silvia A. Fernandez de Gurmendi, 599.

131 Art.7 and 8, Rome Statute of the International Criminal Court, U.N. Doc. A/CONF.183/9; The chapeau of article 7 of the Rome Statute contains the "threshold" for the crimes against humanity, while the chapeau of article 8 contains a non-mandatory "threshold" for war crimes.; Sang-Hyun, Song, 260-261. 
the crime of aggression, which, in terms of customary law, is still shaped by the U.N. Charter and the jurisprudence of the Nuremberg Tribunal. The fact that the Russian criminal code contains the language of Nuremberg demonstrates the impact of Nuremberg on the practice of states. ${ }^{132}$

Experience shows that the prudence displayed in the Rome Conference was wise. One of the reasons why the list of crimes in the Rome Statute has attained such credibility and has had such a significant impact on national legislation is because of the comfort provided to governments, judges, and legislators resulting from the crimes' general conformity with customary law. ${ }^{133}$

During discussions in the PrepCom, various innovative definitions were suggested. Attempts to create a new definition have encountered resistance and raised problems, however, not only because of their conformity with the underlying principle of legality and conformity with customary law, but also because they lower the established threshold of seriousness for the crime of aggression. Such attempts can devalue the crime of aggression by lowering the established threshold of seriousness for this crime and can endanger the possibility to use this crime as a means of resorting to humanitarian interventions at discretion.

A proposal submitted by Bosnia and Herzegovina, New Zealand, and Romania at the $8^{\text {th }}$ session of the PrepCom ${ }^{134}$ improves upon some controversial formulations by introducing a certain threshold into the definition. This proposal defines aggression as "the use of armed force to attack the territorial integrity or political integrity of another State in violation of the Charter of the United Nations." ${ }^{135}$ It seems that the notion of "attacking" territorial integrity or political integrity was intended to ensure that it covered only conduct sufficiently serious in nature as to require accountability in a criminal court.

In other words, this proposal recognizes that not every questionable use of force would amount to a crime of aggression warranting the prosecution in ICC. ${ }^{136}$ However, it is still questionable whether such a proposal follows the customary law which has been established from the Nuremberg Tribunal. Unless customary law is followed and

\footnotetext{
132 Theodor Meron, 9.

133 Ibid.

134 Proposal submitted by Bosnia and Herzegovina, New Zealand and Rumania, Definition of the crime of aggression, U.N. Doc. PCNICC/2001/WGCA/DP.2 (2001)

135 Ibid.

136 Theodor Meron, 11.
} 
the crime is clearly defined in ways that meet the requirements of criminal justice, there will be no agreement on the definition of the crime of aggression.

\subsection{Various Proposals from the Preparatory Commission for the International Criminal Court}

During the last ten sessions of the PrepCom, many proposals were submitted from February, 1999 to July, 2002. With these proposals, the PrepCom made considerable efforts towards reaching an agreement on the definition and jurisdiction of the crime of aggression, but legal and political difficulties related to issues dealing primarily with the use of force in international relations prevented the commission from completing its goal.

Though there was no decisive or positive outcome, no one can deny that significant progress was made on the crime of aggression in the discussions at the PrepCom. A guideline was drawn for this controversial issue regarding the definition of the crime of aggression and the conditions under which the ICC shall exercise jurisdiction, and the role of the U.N. Security Council. ${ }^{137}$

The proposals submitted to the PrepCom can be categorized in 5 types. ${ }^{138}$ The first type is based on the opinion that the prohibition in existing customary law relates only to the planning, preparation, initiation or waging of a "war of aggression," as provided in the Nuremberg Charter. This type of proposals was originally made by France and the Russian Federation in 1996 and by the Russian Federation in $1999 .{ }^{139}$

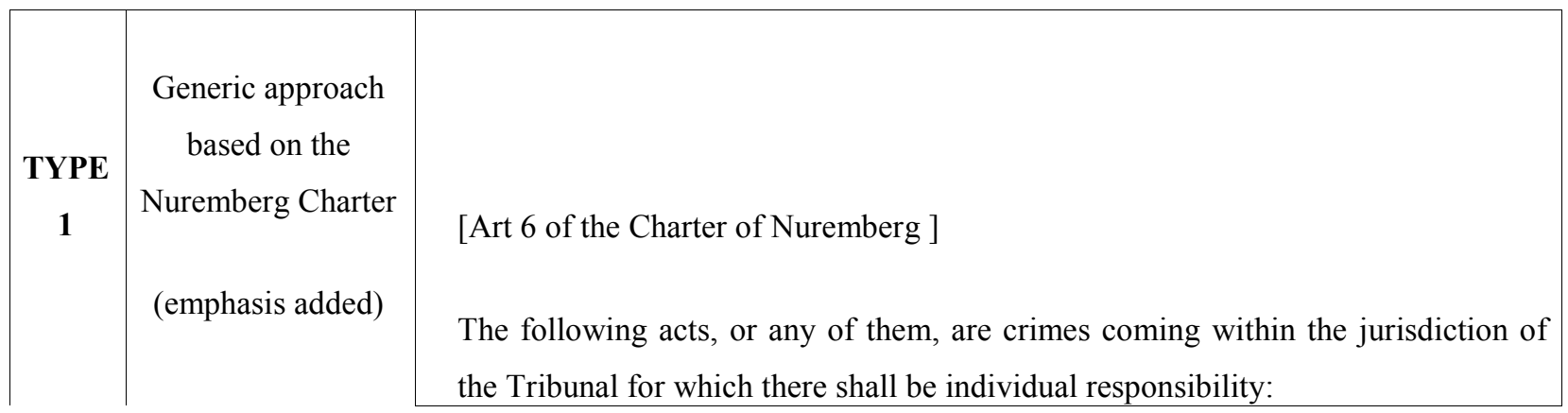

a) Crimes against peace: namely, planning, preparation, initiation or waging of

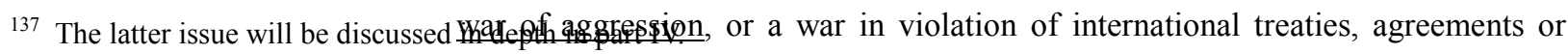

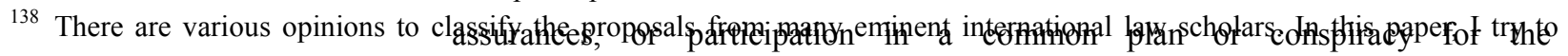
categorize them in five types on ground of the essential characteristics of the crime of aggression which was discussed in part 2.2.

${ }^{139}$ Proposal submitted by the Russian Federation: definition of the crime of aggression U.N. Doc. PCNICC/1999/DP.12 (1999) 


\begin{tabular}{|l|l|}
\hline \multirow{2}{|l|}{} & $\begin{array}{l}\text { accomplishment of any of the foregoing; } \\
\text { [Proposal submitted by the Russian Federation] } \\
\text { For the purposes of the present Statute and subject to a prior determination by the } \\
\text { United Nations Security Council of an act of aggression by the State concerned, } \\
\text { the crime of aggression means any of the following acts: planning, preparing, } \\
\text { initiating, or carrying out a war of aggression. }\end{array}$ \\
\hline
\end{tabular}

A second type provides a general definition of the crime of aggression, centered on the concept of the use of armed force against the sovereignty, territorial integrity or political independence of a state in violation of the UN Charter. This type of proposals was made by Denmark, Greece and Finland in 1996, by Cameroon in $1998,{ }^{140}$ by Greece and Portugal in $1999^{141}$ and $2000,{ }^{142}$ and by Colombia in $2000{ }^{143}$

\begin{tabular}{|c|c|c|}
\hline & $\begin{array}{l}\text { Generic approach } \\
\text { linked with art.2 }\end{array}$ & [November, 28, 2000, Proposal submitted by Greece and Portugal ] \\
\hline $\begin{array}{c}\text { TYPE } \\
2\end{array}$ & $\begin{array}{l}\text { para.4. of the UN } \\
\text { Charter on the } \\
\text { prohibition of the } \\
\text { use of force }\end{array}$ & $\begin{array}{l}\text { For the purposes of the present Statute, the crime of aggression means the use of } \\
\text { armed force (including the initiation thereof) by an individual who is in a position } \\
\text { of exercising control or directing the political or military action of a state against } \\
\text { the sovereignty, territorial integrity or political independence of another state (or }\end{array}$ \\
\hline & & $(\mathrm{es})$, \\
\hline
\end{tabular}

A third type provides the general definition but also insists that the general definition should be accompanied by a non-exhaustive list of acts constituting aggression, taken from General Assembly Resolution 3314 (XXIX) of 1974, to be regarded as an authoritative source of existing law also for the purposes of the Rome Statute. This type

\footnotetext{
${ }^{140}$ Proposal submitted by Cameroon, A/CONF.183/C.I/L.39 in Compilation of Proposals on the crime of aggression submitted at the Preparatory Committee on the Establishment of an International Criminal Court 1996 1998, the United Nations Diplomatic Conference of Plenipotentiaries on the Establishment of an International Criminal Court 1998 and the Preparatory Commission for the International Criminal Court 1999 (hereafter Compilation of Proposals), U.N. Doc. PCNICC/1999/INF/2 (1999) 15 17.

${ }_{141}$ Proposal submitted by Greece and Portugal, U.N. Doc. PCNICC/1999/WGCA/ DP.1 (1999)

142 Proposal submitted by Greece and Portugal, U.N. Doc. PCNICC/2000/WGCA/ DP.5 (2000)

143 Proposal submitted by Colombia on the definition of the crime of aggression and on condition for the exercise of the jurisdiction of the Court with regard to this crime, U.N. Doc. PCNICC/2000/WGCA/DP.1 (2000)
} 
of proposals was made by Egypt and Italy in $1997^{144}$ and by a group of Arab countries in $1998 .{ }^{145}$ Especially, a group of Arab countries added the concept of use of force aimed at depriving other people of their rights of selfdetermination to the general definition in their proposal.

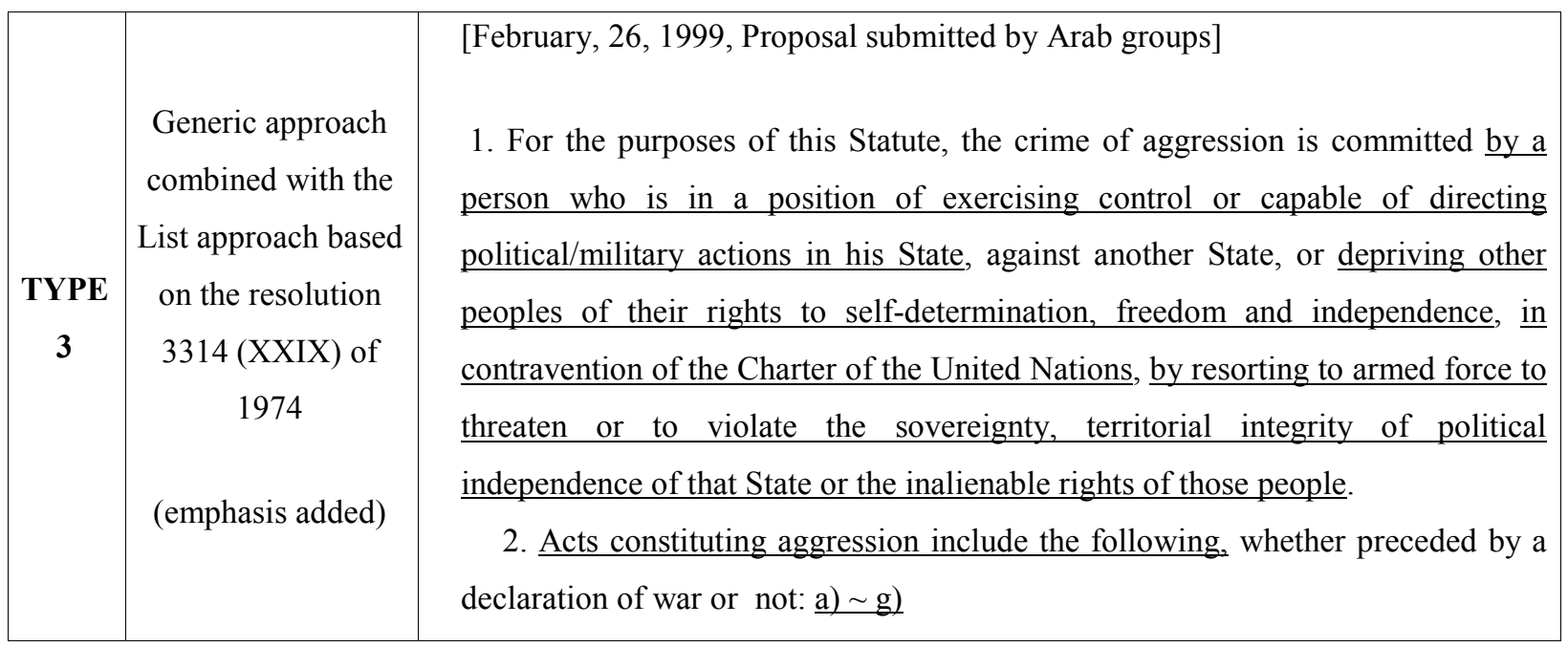

The fourth type links the crime of aggression to the circumstance under which the armed attack of a state had the object or the effect of a military occupation or of an annexation of the territory of another state. The intent of this type of proposals was to cover the most obvious cases of aggression, while avoiding the debate on the other types of acts listed in the resolution 3314(XXIX) of 1974. This type of proposals was made by Germany in $1999^{146}$ and $2000 .{ }^{147}$ Particularly, in its proposal of 2000, Germany reaffirmed that the essence of the crime of aggression presupposes a large scale, aggressive armed attack on the territorial integrity of another State, clearly without justification under international law. ${ }^{148}$

\footnotetext{
${ }^{144}$ Proposal submitted by Egypt and Italy on the definition of aggression, U.N. Doc. A/AC.249/1997/WG.1/DP.6 (1997) in Compilation of Proposals.

${ }^{145}$ Proposal submitted by Bahrain, Iraq, Lebanon, the Libyan Arab Jamahiriya, Oman, the Sudan, the Syrian Arab Republic and Yemen on the crime of aggression, U.N. Doc. PCNICC/1999/DP.11 (1999)

${ }_{146}$ Proposal submitted by Germany: definition of the crime of aggression, U.N. Doc. PCNICC/1999/DP.13 (1999)

147 Proposal submitted by Germany: the crime of aggression - a further informal discussion paper, U.N. Doc. PCNICC/2000/WGCA/DP.4 (2000)

${ }^{148}$ Ibid.
} 


\begin{tabular}{|c|c|c|}
\hline $\begin{array}{c}\text { TYPE } \\
4\end{array}$ & $\begin{array}{l}\text { Generic approach } \\
\text { which limited the } \\
\text { act of aggression } \\
\text { within the purview } \\
\text { of the crime of } \\
\text { aggression } \\
\text { (emphasis added) }\end{array}$ & $\begin{array}{l}\text { [July, 30, 1999, Proposal submitted by Germany ] } \\
\text { 1. For the purpose of the present Statute and subject to a determination by the } \\
\text { Security Council referred to in article 10, paragraph 2, regarding the act of a State, } \\
\text { the crime of aggression means either of the following acts committed by an } \\
\text { individual who is in position of exercising control or capable of directing the } \\
\text { political or military action of a State: } \\
\text { a) initiating, or b) carrying out } \\
\text { an armed attack directed by a State against the territorial integrity or political } \\
\text { independence of another State when this armed attack was undertaken in manifest } \\
\text { contravention of the Charter of the United Nations with the object or result of } \\
\text { establishing a military occupation of, or annexing, the territory of such other State } \\
\text { or part thereof by armed forces of the attacking State. } \\
\text { 2. Where an attack under paragraph } 1 \text { has been committed, the } \\
\text { a) planning, b) preparing, or c) ordering } \\
\text { thereof by an individual who is in a position of exercising control or capable of } \\
\text { directing the political or military action of a State shall also constitute a crime of } \\
\text { aggression. }\end{array}$ \\
\hline
\end{tabular}

The fifth type makes a clear-cut distinction between the concept of the crime of aggression which can give rise to individual criminal responsibility and the concept of aggression by a state which can give rise to international responsibility as a violation of article 2 paragraph 4 of the UN Charter. In this type of proposals, the crime of aggression is clearly defined as a leadership crime committed by a person who is in a particular position within the state and can actually plan, prepare, initiate or wage acts of aggression. Furthermore such proposals try to point out that the referring act should be committed "intentionally and knowingly." As regards the concept of aggression committed by a state, such proposals generally state that it means the use of armed force to attack the territorial integrity or political independence of another state in violation of the Charter of the United Nations. Bosnia and Herzegovina, New Zealand and Romania in $2001^{149}$ made this type of proposals.

\footnotetext{
${ }^{149}$ Proposal submitted by Bosnia and Herzegovina, New Zealand and Rumania, Definition of the crime of aggression, U.N. Doc. PCNICC/2001/WGCA/DP.2 (2001)
} 


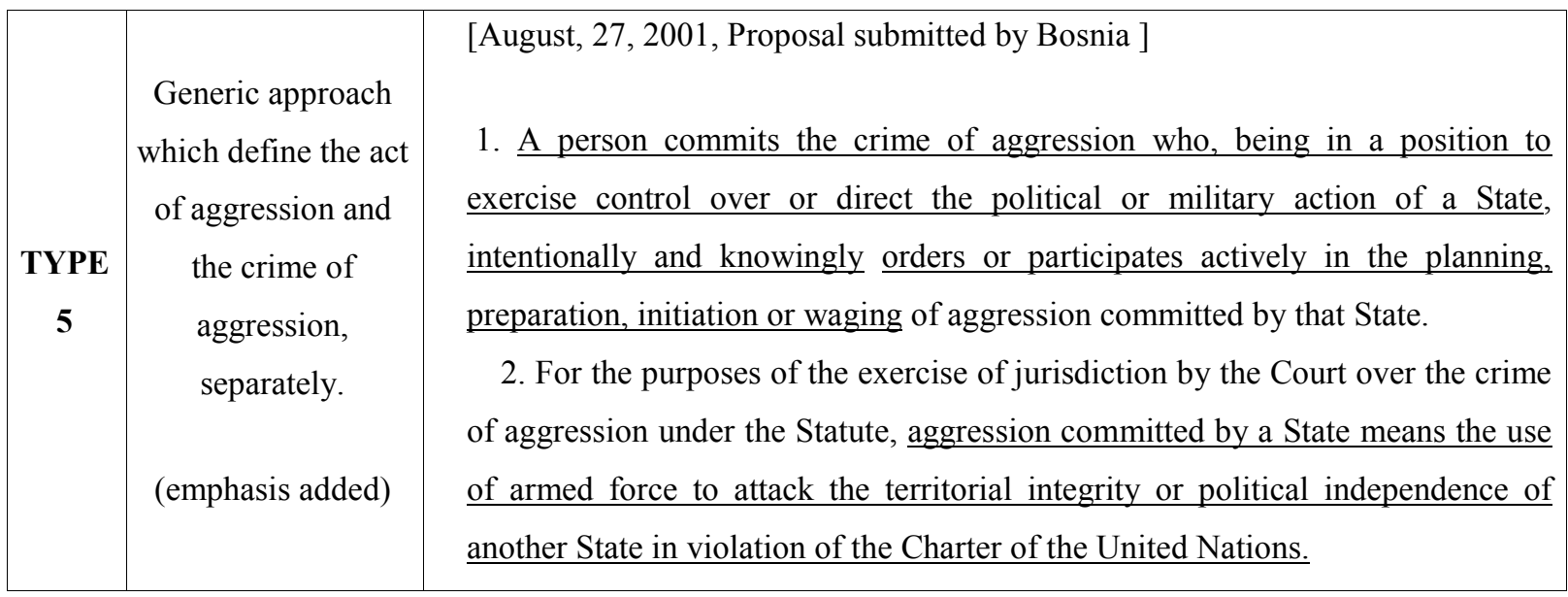

This paper agrees with type 5, generic approach which defines the act of aggression and the crime of aggression, separately. Type 5 contains the formulations included in the Nuremberg Charter related with the crime of aggression and also reflects the article 2 paragraph 4 of the UN Charter related with the act of aggression. It sufficiently shows the essential characteristics of the crime of aggression which were discussed in part 2.2.

The positions of the proposals submitted to PrepCom appear a bit distant, but, are not too distant. And finally, just before the effectuation of the Rome Statute, the Coordinator of the Working Group on the crime of aggression of the ICC prepared the "discussion paper" that reflected all the proposals. ${ }^{150}$

\subsection{Post-Rome Statute, Definitional issues from the Special Working Group on the Crime of Aggression}

After the effectuation the Rome Statute in 2002, a Special Working Group on the Crime of Aggression (hereafter Special Working Group) was established. ${ }^{151}$ During the four sessions from September 2003 to June 2005, this special working group discussed the definition of the crime of aggression and conditions for the exercise of jurisdiction based on the "discussion paper." 152 The definition of the crime of aggression was stipulated in

\footnotetext{
${ }^{150}$ More details will be discussed in next part.

151 U.N. Doc. ICC-ASP/1/L.5 2003

152 Discussion paper proposed by the Coordinator, U.N. Doc. PCNICC/2002/WGCA/RT.1 /Rev.1, (2002)
} 
paragraph 1 and 2 of the discussion paper. ${ }^{153}$

The definition of the crime of aggression follows the methodological approach suggested during the final phase of the PrepCom by Bosnia and Herzegovina, New Zealand and Romania ${ }^{154155}$ and therefore distinguishes between the concept of "crime of aggression" and "act of aggression." In light of nature of the ICC intended to deal only with individual criminal responsibility and taking into account the wording of article 5 of the Rome Statute ${ }^{156}$, the discussion paper focuses exclusively on the definition of the crime of aggression and deliberately refuses to cover the definition of the act of aggression which entails state responsibility.

By doing so, it finally abandons the long controversy between the generic versus list approach, which was very much linked to the contents of resolution 3314(XXIX) of 1974.

In light of this approach, the discussion paper refers in paragraph 1 to the definition of the crime of aggression which is based on an updated formulation of the definition provided by the Nuremberg Charter and the jurisprudence of the Nuremberg and Tokyo Tribunals. This definition summarizes one of the few common understandings that transpired during the debates: the common assumption that only leaders of a state can be criminally held responsible of the crime of aggression. Paragraph 1 is stipulated as below:

1. For the purpose of the present Statute, a person commits a "crime of aggression" when, being in a position effectively to exercise control over or to direct the political or military action of a State, that person intentionally and knowingly orders or participates actively in the planning, preparation, initiation or execution of an act of aggression which, by its character, gravity and scale, constitute a flagrant violation of the Charter of the United Nations.

Immediately after this definition, the text includes three variations which refer to the issue of the "threshold." While one of the variations stipulates that no threshold is in fact required, the others include as thresholds two of the ideas put forward along the debates in order to narrow the uses of force that should be included under the definition of aggression. It is stated as below:

${ }^{153}$ The conditions for the exercise of jurisdiction of the crime of aggression were stipulated in paragraph 4 and 5 of the discussion paper. It will be reviewed in part IV.

${ }^{154}$ Proposal submitted by Bosnia and Herzegovina, New Zealand and Rumania, Definition of the crime of aggression, U.N. Doc. PCNICC/2001/WGCA/DP.2 (2001)

${ }^{155}$ See part 2.1.6.

${ }^{156}$ See note 59. 
Option 1: Add "such as, in particular, a war of aggression or an act which has the object or result of establishing a military occupation of, or annexing, the territory of another State or part thereof"

Option 2: Add "and amounts to a war of aggression or constitutes an act which has the object or the result of establishing a military occupation of, or annexing, the territory of another State or part thereof"

Option 3: Neither of the above

Paragraph 2 of the discussion paper relates the "act of aggression." The document is based on the premise that the definition of the act is not required since this concept relates to state responsibility and has already been defined by the international community through resolution 3314(XXIX) of 1974. Therefore, this part of the document simply refers to this resolution by stating that:

2. For the purpose of paragraph1, "act of aggression" means an act referred to in United Nations General Assembly resolution 3314(XXIX) of 14 December 1974, which is determined to have been committed by the State concerned,

Option 1: Add "in accordance with paragraphs 4 and 5"

Option 2: Add "subject to a prior determination by the Security Council of the United Nations"

As far as we have seen above, the discussion paper tried to summarize the various proposals concerning the definition of the crime of aggression. However, the discussion paper received not much support from the delegates in the ICC. ${ }^{157}$ Their main concern was that the various proposals were oversimplified because the proposed options for the crime of aggression could not be harmonized. In short, such an attempt to find a common ground unfortunately just demonstrated the distances between the various proposals thus far presented.

Therefore, some delegates suggested discussing the elements of crime first and then moving on to a discussion of the definition of the crime of aggression. ${ }^{158}$ It is because the elements of crime can reflect certain aspects that should be part of the definition and as a result it will be a shortcut to reach an agreement on definition of the crime of aggression.

\subsection{Elements of the Crime of Aggression}

The effectuation of the Rome Statute was announced on 1 July, 2002, at the opening of the tenth and last

157 Giuseppe Nesi, 170.

${ }^{158}$ Fourth Session, Special Working Group on the Crime of Aggression, U.N. Doc. ICC-ASP/4/SWGCA/INF.1, (2005) 11. 
session of the PrepCom. During this period, the Netherlands ${ }^{159}$, Samoa ${ }^{160}$, Colombia ${ }^{161}$, the Movement of NonAligned Countries (hereafter NAM) ${ }^{162}$, Belgium, Cambodia, Sierra Leone, and Thailand ${ }^{163}$ had to address new proposals presented by several delegations. One of the most interesting proposals was submitted from the delegation of Samoa. It explained that while the PrepCom was focusing its efforts on the definition of aggression and the conditions under which the ICC should exercise its jurisdiction, the "question of the Elements (of the crime of aggression) should not pass entirely unnoticed with the impending demise of the Preparatory Commission."164

From the perspective view of the Samoan delegate, Professor Roger Clark, the issue of the elements of this crime was important "not only for its own sake, but also, and perhaps more importantly, for the light that it might shed on the technical aspects of the definition and conditions." 165 On this basis, the "discussion paper" proposed by the Coordinator contained the elements of the crime of aggression. ${ }^{166}$ Provision on Elements of Crimes is stipulated in article 9 of the Rome Statute. ${ }^{167}$ "Elements of Crimes" is a quite new concept in international law and discussions in PrepCom and Special Working Group were inevitably in confusion for a time. ${ }^{168}$

Thus, this section will try to conceptualize the crime of aggression like other crimes within the jurisdiction of the Court, in terms of "mental" elements and "material" elements, as found in article 30 of the Rome Statute. Elements of the crime can be considered as basic building blocks that fit together to constitute "a crime." 169 A prosecutor who fails to establish any one of those elements has failed to

\footnotetext{
159 Proposal submitted by the Netherlands, U.N.Doc. PCNICC/2002/WGCA/DP.1 (2002)

160 Proposal submitted by Samoa, U.N.Doc. PCNICC/2002/WGCA/DP.2 (2002)

161 Proposal submitted by Colombia, U.N.Doc. PCNICC/2002/WGCA/DP.3 (2002)

162 Proposal submitted by the Movement of Non-Aligned Countries, U.N.Doc. PCNICC/2002/WGCA/DP.4 (2002)

163 Proposal submitted by Belgium, Cambodia, Sierra Leone, and Thailand, U.N.Doc. PCNICC/2002/WGCA/DP.5 (2002)

164 Proposal submitted by Samoa, U.N.Doc. PCNICC/2002/WGCA/DP.2 (2002)

165 Ibid.

166 Discussion paper proposed by the Coordinator, U.N. Doc. PCNICC/2002/WGCA/RT.1 /Rev.1, (2002)

167 Article 9 paragraph 1 states:

"1. Elements of Crimes shall assist the Court in the interpretation and application of articles 6, 7 and 8 . They shall be adopted by a two-thirds majority of the members of the Assembly of States Parties."

168 Giuseppe Nesi, 171.

169 Proposal submitted by Samoa, para.5.
} 
overcome the "presumption of innocence" 170 or failed to meet the "onus ... to prove the guilt of the accused"171

\subsubsection{Actus reus (Material Elements)}

Material elements mean "circumstances," "conduct" and "consequences" of certain crime in question. $^{172}$ "Conduct" normally refers to an act or omission and a "consequence" is a result of such conduct. The term "circumstances" is a lot more difficult to understand and there is little in the preparatory work to explain what the drafters of article 30 had in mind. ${ }^{173}$ But generally, a circumstance is a crucial factor in the environment in which the actor operates. For example, in the case of genocide, a manifest pattern of similar conduct qualifies as circumstances in the elements.

There are a few material elements that should be carefully discussed in the elements of the crime of aggression in "discussion paper.", 174

Element 1: The perpetrator was in a position effectively to exercise control over or to direct the political or military action of the State which committed an act of aggression as defined in element 5 of theses Elements.

This is probably a conduct element, although some might characterize it as a circumstance element. The essence of it is that the perpetrator placed himself (or allowed himself to be placed) in a defined role. The words "effectively" are aimed both at such cases and at the position of the figurehead head of state who is formally part of the Government but in fact exercises no control. ${ }^{175}$

Element 3: The perpetrator ordered or participated actively in the planning, preparation or execution of the act of aggression.

170 Art.66 of the Rome Statute, title.

171 Ibid, paragraph 2.

172 Young Sok Kim, "General Principle of the Criminal Law in the Statute of the International Criminal Law", Mofat Int'l L. Rev, vol. 2. (2003) 29.

173 Proposal submitted by Samoa, para.9.

${ }^{174}$ Elements of the Crime of Aggression in Discussion paper proposed by the Coordinator, U.N. Doc. PCNICC/2002/WGCA /RT.1 /Rev.1, (2002)

${ }^{175}$ Proposal submitted by Samoa, art.5. note (c) 
This is a conduct element. "participated actively" includes an understanding that there was a nexus between the perpetrator's conduct and the act of aggression. It is doubtful whether there can be an "attempted aggression" by a state. Accordingly, the kind of attempts that would be contemplated are those where the actor tries to contribute to the "planning, preparation, initiation or waging" of an aggression that takes place, but he or she fails in the effort to contribute. ${ }^{176}$ This paper argues that liability might be appropriate for attempts in some such cases.

\subsubsection{Mens rea (Mental Elements)}

Mental elements in the Statute and the Elements are intent and knowledge. ${ }^{177}$ Article 30 of the Rome Statute is titled "Mental element" and it contemplates that "unless otherwise provided," there is no criminal responsibility in the absence of "intent and knowledge" in respect of what the article calls "material elements." 178

There are a few mental elements that should be carefully discussed in the Elements of the crime of aggression in the "discussion paper." 179

Element 2: The perpetrator was knowingly in that position.

Element 4: The perpetrator committed element 3 with intent and knowledge.

Element 2 and 4 are both mental elements. These elements are probably redundant, since the article 30 of the Rome Statute already states them. However, it has been included out of an abundance of caution, as in the case of the phrase "with knowledge of" in the chapeau of article 7 of the Rome Statute. Another

176 Proposal submitted by Samoa, para. 17.

177 Young Sok Kim, 28.

178 Drafts of the Statute had consistently used the term "physical elements." The word "material" was substituted in the Drafting Committee at a very late stage, evidently with no intention to change the meaning.; Proposal submitted by Samoa, U.N.Doc. PCNICC/2002/WGCA/DP.2 (2002) para.6.

${ }^{179}$ Elements of the Crime of Aggression in Discussion paper proposed by the Coordinator, U.N. Doc. PCNICC/2002/WGCA /RT.1 /Rev.1, (2002) 
notable point is that the requirement which the aggression be done knowingly by the accused leads directly into potential mistakes of fact or of law that the accused may have made ${ }^{180}$.

\subsection{Conclusion: Harmonization of Positions}

This chapter argues that most of the proposals in the PrepCom and one in the "discussion paper" revolve around the fundamental question as to the content of customary international law relating to the crime of aggression, today. This chapter believes that customary law is not only reflected in the Nuremberg Charter which refers to a fullscale war of aggression, but also it has developed up to the point of including other acts of aggression. Precedents such as resolution 3314(XXIX) of 1974 can be helpful to determine the scope of the act of aggression which reaches to the extent of individual criminal responsibility.

At least, in the Special Working Group on the Crime of Aggression, there is an agreement on the "generic approach" for the definition of the crime of aggression, since it gives the ICC the necessary flexibility in assessing whether an act would present the characteristics to be considered as a crime of aggression. Such discretion gives the ICC a better chance to prosecute and punish the crime of aggression. However, it may increase the risks of politically motivated complaints and of conflicts in the ICC's judgment.

Many problems like the 'threshold issue' still remain without an agreement. But through the constant efforts by the PrepCom and the Special Working Group, there were positive developments and that probably it is not too far from reaching a definition of the crime of aggression which has unanimous consent.

This paper suggests three points that should be in the definition of the crime of aggression. First, it should follow the "generic approach," because it is not necessary to limit the discretion of the ICC too strictly and also because the ICC will need to prosecute and punish the future crime of aggression.

Second, the crime of aggression and act of aggression should be separately stipulated in the definition. Concerning the crime of aggression, the scope of it should not be limited to the one in the Nuremberg Charter. Also,

180 Article 32 of the Rome Statute on Mistake of Fact or Mistake of Law.

$$
\text { - } 39 \text { - }
$$


the act of aggression should be defined narrowly based upon the contents of the resolution 3314(XXIX) of 1974 that should be considered as customary international law to some extent. Surely, the "threshold issue" should be defined before hand.

Third, the definition should comply with the principle of legality. Thus essential elements should be included in it. The crime of aggression should not be treated differently from other crimes within the jurisdiction of the ICC just because of its political nature. 


\section{Jurisdiction of the Crime of Aggression}

This chapter argues that first the Security Council's primary responsibility for determining the existence of the state aggression should be confirmed. Second, the Security Council's exclusive right to make such determinations should be denied and there should be a provision which make legally possible for the General Assembly of the United Nations or the International Court of Justice to make such determinations in case of absence of the determination from the Security Council. Third, to decide whether to give such secondary right to the General Assembly of the United Nations or the International Court of Justice should be settled by a political compromise through a structured, and such a debate should be opened not only to the state party to the Rome Statute but also to all UN members.

\subsection{The respective roles of the International Criminal Court and the Security Council in Determining an}

\section{Act of Aggression}

The relationship between the Security Council and the ICC has caused more controversy and consumed more time than any other issues related to the Rome Statute. ${ }^{181}$ In general, that relationship is regulated by article 5 paragraph 2, article $13(\mathrm{~b})^{182}$ and article $16^{183}$ of the Rome Statute. However, the relationship between the ICC and the Security Council with respect to aggression is regulated by article 5 of the Rome Statute, while paragraph 2 of this article does not make explicit reference to the Security Council. ${ }^{184}$

\footnotetext{
181 Mohammed M. Gomaa, 74.

182 Article 13 (b) on Exercise of jurisdiction states:
}

"(b) A situation in which one or more of such crimes appears to have been committed is referred to the Prosecutor by the Security Council acting under Charter VII of the Charter of the United Nations; or"

183 Article 16 on Deferral of investigation or prosecution states:

"No investigation or prosecution may be commenced or proceeded with under this Statute for a period of 12 months after the Security Council, in a resolution adopted under Chapter VII of the Charter of the United Nations, has requested the Court to that effect; that request may be renewed by the Council under the same conditions."

184 To coordinate the roles of the two bodies, ILC had attempted to resolve in its draft Statute by making a determination by the Security Council a condition for the ICC to be able to try an individual for aggression. Article 23 paragraph 2 stipulated that it would be necessary "to ensure that prosecutions are brought for aggression only if the Security Council first determines that the state in question has committed aggression."; Report of the International Law Commission on the work of its $46^{\text {th }}$ Session, U.N. GAOR, 49 ${ }^{\text {th }}$ Sess., Supp. No.10, U.N.Doc A/49/10 (1994) 72. 
Article 5 paragraph 2 of the Rome Statute indicates that regard to aggression, the amendment "defining the crime and setting out the conditions under which the Court shall jurisdiction with respect to this crime" should be "consistent with the relevant provisions of the Charter of the United Nations." 185 This clearly concerns the respective decisions by the Security Council and the ICC that a state has or has not committed aggression. For the ICC, such decision is essential because a crime of aggression would be inconceivable under international law without a state having committed aggression, as stated in part 2.2.1.

There is no ambiguity in the UN Charter that it entrusts the Security Council with the task of determining the existence of any act of aggression in accordance with article $39^{186}$ and article 24. However, any such determination by the Security Council will not be without legal effects on the ICC whether it is positive or negative. For example, if the Security Council declares a case of aggression, the ICC will be able to exercise its jurisdiction over this crime of aggression. But a finding by the ICC that there was no legal linkage between a situation of aggression as determined by the Council and the act of the individuals alleged to be implicated in it will surely put in question that determination. Such a case would put the ICC in direct conflict with the Security Council. On the other hand, if the Council failed to make a determination for whatever reasons that there existed an act of aggression ${ }^{187}$, the ICC would not be able to exercise its jurisdiction with respect to aggression if the Security Council were the only organ allowed to make such determinations.

Therefore, it may not be argued that under the UN Charter, the Security Council has exclusive power to make a decision on the existence of aggression, nor that a determination by the Security Council would be binding upon the ICC which was entrusted with the repression of individual crimes.

185 This provision is related with the article 103 of the UN Charter. It states:

"In the event of a conflict between the obligations of the Members of the United Nations under the present Charter and their obligations under any other international agreement, their obligations under the present Charter shall prevail."

186 Article 39 states:

"The Security Council shall determine the existence of any threat to the peace, breach of the peace, or act of aggression and shall make recommendations, or decide what measures shall be taken in accordance with Articles 41 and 42 , to maintain or restore international peace and security."

${ }^{187}$ For instance, in connection with the Suez crisis in which Member states of the United Nations were called upon to assist the Security Council under article 42 of the UN Charter to halt the aggression, France and the United Kingdom used their veto right to block the resolution.; Mohammed M. Gomaa, 75. 


\subsection{The Problem of Politicization}

The Security Council has been extremely reluctant to find that there has been an act of aggression. In almost 60 years of activity, the Security Council has done so once under the Security Council Resolution (hereafter SC resolution) 387 of 1976 which condemned "South Africa's aggression against the People's Republic of Angola."188 Even Iraq's invasion of Kuwait was only defined as a "breach of the peace" under SC resolution 661 of $1990{ }^{189}$ Preamble paragraphs in SC resolution 418 of 1977 and SC resolution 527 of 1982 referred to South Africa's "aggressive acts" on its neighboring States and on Namibia, but the Security Council still found that there only was a threat to the peace. ${ }^{190}$

Therefore, a few scholars and delegations in the ICC argue that in view of this habitual practice in the Security Council, the ICC should not be dependent upon a finding of a previous assessment by the Security Council concerning aggression, because this would deprive the provision on aggression in the Rome Statute of almost its meaning. ${ }^{191}$

However, to ask the ICC in the absence of a determination by the Security Council to decide that an act of aggression has taken place would endanger its judicial role and image. ${ }^{192}$ Surely, there will be immense difficulties for the ICC in dealing even with relatively simple acts of aggression. The ICC has no right to handle such matters as historical claims to territory, maritime boundaries, or legitimate self-defense under article 51 of the UN Charter. Furthermore, the competence of the ICC is limited to jurisdiction over natural persons as stated before. Thus, it is important for the ICC not to turn into a political forum discussion the legality of use of force by States. ${ }^{193}$ And it is so-called a problem of "politicization." 194 The problem is that there may be some legitimate overlap between the political and the judicial functions in the sense that the boundaries between the different functions are less clear than what the argument of politicization tries to say.

\footnotetext{
188 Christine Gray, 197.

189 Ibid.

190 Ibid, 198.

191 Girgio Gaja, "The Long Journey towards Repressing Aggression," in The Rome Statute of the International Criminal Court: A Commentary, ed. Antonio Cassese, Paola Gaeta, and John R.W.D. Jones (Oxford University Press, 2002) 432-434.

192 Theodor Meron, 13.; Marja Lehto, "The ICC and the Security Council: About the Argument of Politicization" in The International Criminal Court and the Crime of Aggression, ed. Mauro Politi and Giuseppe Nesi, (Ashgate, 2004) 146.

193 Theodor Meron, 13

194 Marja Lehto, 146.
} 
It is clear that the Security Council has different functions from those of international courts like ICC or ICJ. The process in the Security Council is very different from judicial proceedings. The Security Council is a political organ with wide discretionary powers. Thus it can be said that its determination under article 39 of the UN Charter that an act of aggression has taken place is a result of political considerations. ${ }^{195}$

Judge Schwebel wrote in his dissenting opinion to the Nicaragua case in 1984 that "the Security Council may take legal considerations into account but unlike a court, is not bound to apply them." ${ }^{196}$ While this continues to be a highly relevant remark, we should notice a significant development in the practice and policy of the Security Council over the past 20 years. ${ }^{197}$ The role of the Security Council has become increasingly central in the enforcement of international legal norms. The Security Council has not only taken into account legal considerations but has also made legal determinations, sometimes of a type "that is in the heart of what is normally seen as judicial activity. ... Determinations of international law are now part and parcel of decision-making on collective measures." ${ }^{\prime 198}$ Thus, it can be said that there is a quasi-judicial role of the Security Council.

Conversely, have there been similar changes concerning the judicial function of international court like ICJ? In Nicaragua case, the ICJ stated in its dictum that "The Council has functions of a political nature assigned to it, whereas the Court exercises purely judicial functions." ${ }^{199}$ But, then the ICJ concludes that both the Security Council and the ICJ "can therefore perform their separate but complementary functions with respect to the same events."200 In case of the ICC, it seems different from the ICJ as it has jurisdiction over individuals not states.

However, at least one thing is clear that the relationship between the two international bodies is very close and complex. As stated before, the ICC is already integrated in the system of the United Nations by article 13 and 16 of the Rome Statute. Thus, concerning the conditions for the jurisdictions of the crime of aggression, it should choose the one that can avoid any conflict in the relationship between the ICC and the Security Council. In the next

\footnotetext{
195 Ibid, 147.; It may be the reason why the Security Council has been so reluctant to find the existence of the aggression and preferred to use the concepts of threat against the peace or breach of the peace as a basis for actions under article 39 of the UN Charter. Girgio Gaja, 433.

196 Military and Paramilitary Activities in and against Nicaragua (Nicaragua v. United States of America), ICJ Reports (1986) 290.

197 Marja Lehto, 147.

198 Rosalyn Higgins, Problems and Process, (Oxford University Press, 1994) 182.

199 Military and Paramilitary Activities in and against Nicaragua, ICJ Reports (1986) 435.

200 Ibid.
} 
two parts, the way delegations in the PrepCom and the Special Working Group have handled this problem will be reviewed with various proposals.

\subsection{Discussion of the various Proposals from the Preparatory Commission}

Some delegations in the PrepCom insisted that the "Security Council has the exclusive power to determine whether an act of aggression has been committed."201 At the Rome Conference, Cameroon proposed that "the Security Council shall determine the existence of aggression in accordance with the pertinent provisions of the Charter of the United Nations before any proceedings take place in the Court in regard to a crime of aggression."202 Two more proposals submitted to the PrepCom after the Rome Conference follow the same line. The Russian Federation proposed that a definition of aggression was made "subject to a prior determination by the United Nations Security Council. ${ }^{203}$ A similar proposal was made by Germany. ${ }^{204}$

Conversely, there are some proposals that did not give an exclusive role to the Security Council. A proposal submitted by Greece and Portugal suggested that "the Court shall exercise its jurisdiction with regard to this crime subject to a determination by the Security Council, in accordance with Article 39 of the Charter, that an act of aggression has been committed by the State concerned." ${ }^{205}$ If the Security Council has not made such a determination, the ICC will make a request to this end. However, according to the same proposal, "if the Security Council does not make such a determination or does not make use of Article 16 of the Statute within 12 months of the request, the Court shall proceed with the case in question."206

Another proposal submitted by Bosnia and Herzegovina, New Zealand and Romania, offers a variation of the same approach, by stating that "where the Security Council makes no such determination, or does not invoke Article

201 Report of the Preparatory Committee on the Establishment of an International Criminal Court, U.N. Doc. A/51/22, (1998) 32.

202 Proposal submitted by Cameroon, A/CONF.183/C.I/L.39; The proposal included a paragraph which stated that, if the Security Council delayed a reply to the Court's request for a declaration on the existence of aggression, the ICC could "commence an investigation for the purpose of establishing whether a crime of aggression within the meaning of the present Statute exists."

203 Proposal submitted by the Russian Federation: definition of the crime of aggression U.N. Doc. PCNICC/1999/DP.12 (1999)

204 Proposal submitted by Germany: definition of the crime of aggression U.N. Doc. PCNICC/1999/DP.13 (1999)

${ }^{205}$ Proposal submitted by Greece and Portugal, U.N. Doc. PCNICC/2000/WGCA/DP.5 (2000)

206 Ibid. 
16, within twelve months from the date of notification by the Court, the Court may notify the General Assembly of the situation before the Court and invite the General Assembly to request the International Court of Justice, in accordance with Article 96 of the Charter, to give an advisory opinion on the legal question of the existence or otherwise of an act of aggression by the State concerned." Only if the ICJ "delivers an advisory opinion that there has been an act of aggression by the State concerned, and the General Assembly so recommends," may the ICC proceed. ${ }^{207}$

All these proposals try to bridge the gap between positions that defend the exclusive responsibility of the Security Council in determining aggression of a state, taken as a pre-requisite for deciding on individual criminal responsibility, and those that argue that the Security Council has no role at all in this matter, since the determination of aggression of a State is a legal question that was not assigned by the UN Charter to the Security Council. These compromise proposals all agree that the "primary" responsibility for determining State aggression lies in the Security Council, but also considered that a failure by this institution to fulfill this responsibility can not make the jurisdiction of the ICC ineffective and nonexistent in practice. They suggest leaving the determination of such a situation to another political organ like the General Assembly, or to a judicial organ like the ICC itself, or to a mix of judicial and political organs like the ICJ and the General Assembly.

And finally, just before the effectuation of the Rome Statute, the Coordinator of the Working Group on the crime of aggression of the ICC prepared the "discussion paper"208 that reflected all the proposals.

\subsection{Post-Rome Statute, Issues from the Special Working Group on the Crime of Aggression}

As regards the conditions for the exercise of jurisdiction of the crime of aggression, the "discussion paper" stipulates it in paragraph 4 and paragraph 5. The issues related to the conditions for the exercise of jurisdiction are probably far more difficult to resolve than the definition of the crime. The discussion paper does not attempt to push one of the various proposals submitted during the discussions, but just compiled them. However, it moves forward

207 Proposal submitted by Bosnia and Herzegovina, New Zealand and Rumania, U.N. Doc. PCNICC/2001/WGCA/DP.2 (2001)

208 Discussion paper proposed by the Coordinator, U.N. Doc. PCNICC/2002/WGCA/RT.1 /Rev.1, (2002) 
from the ambivalent views reflected in the content of article 5 of the Rome Statute ${ }^{209}$ by accepting the assumption that the Security Council has the primary role in defining the act of aggression. Also, it proposes three possible courses of action, in case of inaction by the Security Council.

\subsubsection{Role of the Security Council in defining the Act of Aggression}

Based on the article 39 of the UN Charter, there are no opinions which deny the "primary role" of the Security Council to determine an act of aggression. However, this has not been considered from the letter and spirit of this article that powers granted to the Security Council are exclusive. ${ }^{210}$ In discussion paper, it is stated in paragraph 4, as below.

4. Where the Prosecutor intends to proceed with an investigation in respect of a crime of aggression, the Court shall first ascertain whether the Security Council has made a determination of an act of aggression committed by the State concerned. If no Security Council determination exists, the Court shall notify the Security Council of the situation before the Court so that the Security Council may take action, as appropriate:

Option 1: under Article 39 of the Charter of the United Nations.

Option 2: in accordance with the relevant provisions of the Charter of the United Nations.

It clearly shows that the primary responsibility for determining the existence of the state aggression lies in the Security Council and concerning this view, so far as, there are no controversies between delegations in the Special Working Group on the crimes of aggression. ${ }^{211}$

However, it might be argued that "the primary responsibility for the maintenance of international peace and security" conferred on the Security Council in accordance with article 24, paragraph 1 of the UN Charter ${ }^{212}$, and consequently the Security Council should play a prominent role in deciding an act of aggression. But, such "primary responsibility" of the Security Council in respect of the maintenance of international peace and security should not

209 See part 4.1.

${ }^{210}$ Saeid Marzaee Yengejeh, "Reflections on the Role of the Security Council in Determining an Act of Aggression" 127, in The International Criminal Court and the Crime of Aggression, ed. Mauro Politi and Giuseppe Nesi, (Ashgate, 2004)

${ }^{211}$ Paula Escarameia, "The ICC and the Security Council on Aggression" 139-141, in The International Criminal Court and the Crime of Aggression, ed. Mauro Politi and Giuseppe Nesi, (Ashgate, 2004)

212 Article 24, paragraph 1 of the UN Charter stipulates that:

" 1 . In order to ensure prompt and effective action by the United Nations, its Members confer on the Security Council primary responsibility for the maintenance of international peace and security, and agree that in carrying our its duties under this responsibility the Security Council acts on their behalf." 
be an exclusive power. This issue has been discussed in the General Assembly in the course of the debate prior to the adoption of the Uniting for Peace Resolution. ${ }^{213}$ In addition to articles 11 and 14 of the UN Charter, article 10 of the UN Charter ${ }^{214}$ gives the General Assembly the right to make recommendations to Member States on any matter within the scope of the Charter. ${ }^{215}$

The question of the "primary responsibility "also has been examined by the ICJ in the Case concerning Certain Expenses of the United Nations. The ICJ found that the primary responsibility does not necessarily mean exclusive authority. ${ }^{216}$ Thus, in the view of the ICJ, the primary responsibility has been granted to the Security Council to maintain peace and security by taking action against those which infringe the fundamental norms and principles of international law including those who resort to the use of force. ${ }^{217}$ Obviously, failure of the Security Council to react properly in case of an act of aggression can not be justified under the cloak of the "primary responsibility." And controversies come from such circumstances in which, the Security Council fails to fulfill the primary responsibility for determining State aggression. As stated before, there are basically three possible ways to deal with such situations, which will be discussed in part 4.4.2. to 4.4.4.

\subsubsection{Type 1: the General Assembly's role}

If an aggression takes place and the Security Council, on political grounds or not, fails to recognize the aggressor state, the first possible way to deal with this thorny situation is to request the General Assembly of the United Nations to make a recommendation. In the discussion paper, it is stated in paragraph 5, option 3 as below.

5. Where the Security Council does not make a determination as to the existence of an act of aggression by a State,

Option 3: the Court shall, with due regard to the provisions of Article 12,14 and 24 of the Charter, request

\footnotetext{
${ }^{213}$ More details will be discussed in part 4.4.2.

214 Article 10 of the UN Charter stipulates that:

"The General Assembly may discuss any questions or any matters within the scope of the present Charter or relating to the powers and functions of any organs provided for in the present Charter, and, except as provided in Article 12, may make recommendations to the Members of the United Nations or to the Security Council or to both on any such questions or matters."

215 Saeid Marzaee Yengejeh, 127-128.

216 The Certain Expenses of the United Nations (Article 17, Paragraph 2, of the Charter), Advising Opinion of 20 July 1962 , (Case Summaries), http://www.icj-cij.org (accessed 6 April, 2006)

217 Saeid Marzaee Yengejeh, 128. 
the General Assembly of the United Nations to make a recommendation within [12] months. In the absence of such a recommendation, the Court may proceed with the case.

In accordance with this view, the General Assembly can play a role in cases of the failure of the Council in determining the aggressor. Proponents of this view believe that in cases of the failure of the Security Council, the Uniting for Peace Resolution ${ }^{218}$ should be invoked to convene the Special Emergency Session of the General Assembly to make a recommendation on the commission of an act of aggression. ${ }^{219}$ For historical reasons, the composition of the Security Council does not represent the current membership of the United Nations. In such a circumstance, a recommendation from the General Assembly, embodying the entire membership of the United Nations, should be acceptable to all its members. Therefore, if the Members of the United Nations decide, a formulation on the basis of the practice of the United Nations could be developed. ${ }^{220}$ However, such proposal can just bring another political controversy connected with the issue of strengthening the power of the General Assembly. Also, it can only make much more difficult to reach a compromise between the countries.

\subsubsection{Type 2: the International Court of Justice's role}

The second possible way is to require the International Court of Justice to make a ruling in such circumstances. In the discussion paper, it is stated in paragraph 5, option 4 as below.

5. Where the Security Council does not make a determination as to the existence of an act of aggression by a State,

Option 4: the Court may request

Variant (a) the General Assembly

Variant (b) the Security Council, acting on the vote of any nine members, to seek an advisory opinion from the International Court of Justice, in accordance with Article 96 of the Charter and Article 65 of the Statute of the International Court, on the legal question of whether or not an act of aggression has been committed by the State concerned. The Court may proceed with the case if the

\footnotetext{
218 General Assembly Resolution 377 (V) 3, November 1950

219 Saeid Marzaee Yengejeh, 128-129; ; Part A of that resolution provides that if the Security Council, because of lack of unanimity of the permanent members, fails to exercise its primary responsibility for the maintenance of international peace and security the General Assembly shall consider the matter immediately. That resolution has been invoked on several occasions to convene the Emergency Special Session of the General Assembly. The Security Council itself on a number of cases has invoked this resolution and called for the Emergency Special Session of the General Assembly.; Yugoslavia in 1956 suggested the first such session to consider the Suez Canal crisis (Security Council Resolution 119, 1956.) There are more examples like Hungarian crisis (S/RES/120), Lebanese crisis in 1958 (S/RES/129), Congo problem in 1960 (S/RES/157), Bangladesh problem in 1971 (S/RES/303), and intervention in Afghanistan in 1980 (GA Res. ES-6/2)

220 Ibid, 131 .
} 
International Court of Justice gives an advisory opinion that an act of aggression has been committed by the State concerned.

Following this view, the ICC can seek to request the advisory opinion of the ICJ in case of failure of the Security Council in discharging its responsibility. It is basically based on article 96 of the UN Charter. ${ }^{221}$ The ICJ is the judicial organ of the United Nations. Both the Security Council and the General Assembly have the competence to request an advisory opinion on any legal question from the ICJ. If the Security Council fails to make a decision on an aggression, and if it does not make a request for an advisory opinion from the ICJ, the Uniting for Peace Resolution could be invoked to request an advisory opinion. ${ }^{222}$ First, the advantages of this procedure can be that it is based on provisions of the UN Charter. And second, the ICJ as the judicial organ has the competence to provide an impartial and independent advisory opinion.

But there are also a few objections to this view. First, whether to give an advisory opinion or not is solely the scope of discretion of the ICJ based on the article 65 of the Statute of the International Court of Justice ${ }^{223}$ (hereafter ICJ Statute). It means that ICJ can refuse to issue the requested opinion in certain circumstances. Second, the determination of an act of aggression would be a question of fact, and this can limit the role of the ICJ. If a question is not legal one, the ICJ should decline to give the requested opinion. ${ }^{224}$ Lastly, article 119 paragraph 2 of the Rome Statute only allows the ICJ to make determinations in disputes between states parties as to the interpretation of the Rome Statute. ${ }^{225}$ However, the ICJ is not allowed to intervene in a dispute between a state party and a non-state party. Furthermore, any intervention by the ICJ is allowed only after the dispute between states parties has been referred to the ICJ by the Assembly of States Parties. This clearly limits the role of the ICJ related with this

221 Article 96 of the UN Charter stipulates that:

"1. The General Assembly or the Security Council may request the International Court of Justice to give an advisory opinion on any legal question.

2. Other organs of the United Nations and specialized agencies, which may at any time be so authorized by the General Assembly, may also request advisory opinions of the Court on legal questions arising within the scope of their activities."

222 See note 219.

223 Article 65 paragraph 1 of the ICJ Statute states:

" 1 . The Court may give an advisory opinion on any legal question at the request of whatever body may be authorized by or in accordance with the Charter of the United Nations to make such a request."

224 James Nicholas Boeving, "Aggression, International Law, and the ICC: an Argument for the Withdrawal of Aggression from The Rome Statute,” 43 Colum. J. Transnat'l L. 557 (2005) 581.

225 Article 119 paragraph 2 of the Rome Statute states:

"2. Any other dispute between two or more States Parties relating to the interpretation or application of this Statute which is not settled through negotiations within three months of their commencement shall be referred to the Assembly of States Parties. The Assembly may itself seek to settle the dispute or make recommendations on further means of settlement of the dispute, including referral to the International Court of Justice in conformity with the Statute of that Court." 
proposal. $^{226}$

\subsubsection{Type 3: the International Criminal Court's determination}

The third possible way is to assign the ICC itself to make a ruling in the absence of the determination by the Security Council. In the discussion paper, it is stated in paragraph 5, option 1 as below.

5. Where the Security Council does not make a determination as to the existence of an act of aggression by a State,

Option 1: the Court may proceed with the case.

In accordance with this option, the ICC itself should make a ruling as to the determination of aggressor in cases of failure of the Council. As prescribed in article 13 (a), the Security Council may refer "a situation in which one or more of the crimes" within the jurisdiction of the ICC "appears to have been committed" to the ICC. Thus, from the view of this proposal, there is no reason to believe that a situation, in which the crime of aggression is believed to have been committed, could not be referred to the ICC by the Security Council.

This position also emphasizes that the ICC comprises of 18 judges to be elected "from among persons of high moral character, impartiality and integrity" who possess the qualification required to be appointed "to the highest judicial offices." 227 It suggests that such a court would not be in a position to render a judgment in cases of alleged commission of an act of aggression. ${ }^{228}$

However, as stated in part 4.2., to ask the ICC to decide the existence of an act of aggression would force the ICC to be wrapped up in political controversies and as a result it can endanger the ICC's judicial role and duty. ${ }^{229}$ It is because the ICC is a court concerning individual criminal responsibility and an aggression is an act of a state.

\footnotetext{
226 James Nicholas Boeving, 581.

227 Article 36, paragraph 3 (a) of the Rome Statute.

228 Saeid Marzaee Yengejeh, 131.

229 Theodor Meron, 13.
} 


\subsection{Conclusion: Overlapping Competencies?}

Aggression is a crime that, unlike all the other crimes covered by the Rome Statute, is committed by a collectivity such as a state and not by an individual, who alone falls under the jurisdiction of the ICC. And, as such, the ICC can not exercise its jurisdiction over it directly.

Thus, as for the determination of situations of aggression, at least, two findings should be remembered. First, the Security Council has the primary responsibility to determine the act of aggression, but it is not the sole authority vested with powers in this respect. It is practically and legally possible for the General Assembly of the United Nations or the International Court of Justice to make such determinations.

Second, the conditions of the ICC to exercise its jurisdiction over the crime of aggression have been made difficult because of the fact that at the time of constructing the UN Charter, it did not expect permanent international criminal cases in international judicial system and as a result did not include such provisions. ${ }^{230}$ Thus when drafting the wide and powerful privileges of the Security Council, the role of other future institutions like the ICC was not foreseen.

Accordingly, the concern over the possible incompatibility between the Rome Statute and the UN Charter has contributed to the delay in a compromise on the provisions on the crime of aggression. The delegations at the PrepCom and Special Working Group were quite aware that while the determinations by the Security Council on act of aggression was a political decision, the ICC was required to review the situation by applying a totally different procedure under a judicial process. This difference in the assessment systems of the ICC and the Security Council can result in different findings. Therefore, any sound solution to the question of the relationship between the ICC and the Council will depend primarily on how it eliminates the possibility of inconsistency between the decisions of the two institutions. Surely, this has to be done with a full respect to the independence of the ICC so that it may fulfill its role for the international justice.

230 Mohammed M. Gomaa, 64-66. 


\section{Conclusion}

This paper discussed the historical background and the essential characteristics of the crime of aggression, definition of this crime and conditions for the exercise of jurisdictions. This paper compiled and categorized various proposals from Member States of the Rome Statute on the definition and jurisdiction of the crime of aggression. Also it tried to point out that should not be forgotten to have a compromise on the definition and jurisdiction of this crime based on the historical progress of it.

Concerning the definition of the crime of aggression, this paper concluded that first the definition of this crime should follow the "generic approach." Second, the crime of aggression and the act of aggression should be separately stipulated in the definition. That is, the crime of aggression should contain the provisions included in the Nuremberg Charter and also reflect the general recognition on it developed up the point of current circumstances. The act of aggression should follow the provisions of precedents such as resolution 3314(XXIX) of 1974 and the ILC Draft Code of Crimes against the Peace and Security of Mankind 1996. Third, the definition of the crime of aggression should comply with the principle of legality. Thus essential material and mental elements of crime should be included in it.

Concerning the jurisdiction of the Crime of aggression, this paper concluded that first the Security Council's primary responsibility for determining the existence of the state aggression should be confirmed. Second, the Security Council's exclusive right to make such determinations should be denied and there should be a provision which make legally possible for the General Assembly of the United Nations or the International Court of Justice to make such determinations in case of absence of the determination from the Security Council. Third, to decide whether to give such secondary right to the General Assembly of the United Nations or the International Court of Justice should be settled by a political compromise through a structured and clear debate and the room for such debate should be opened not only to the state party to the Rome Statute, but also to all UN members.

As a conclusion, this paper would maintain the following three arguments. First, the crime of aggression should not be treated differently than other crimes within the jurisdiction of the ICC. Just because of the political nature of the issues involved, no attempts should be made to depart from the principle of legality. It is important since the principle of legality can be not only a safeguard for the rights of accused, but also can be the best 
protection for the credibility of the ICC.

Second, the ICC is the first institution since the creation of the United Nations to have jurisdiction over individuals for the crime of aggression, which has not foreseen when the UN Charter was drafted. Therefore, legal guidance is at most partial, and a political compromise through a structured and clear debate seems to be the only way to successfully provide for satisfiable definitions of the crime of aggression and conditions for the exercise of jurisdiction. In accordance with this view, the forthcoming works on the ICC of the crime of aggression should be opened not only to the states party to the Rome Statute, but also to all UN members. Furthermore, the states parties to the Rome Statute must make every possible effort to urge all the states that are not parties to join the membership of the Rome Statute for the sake of achieving universality.

Third, contrary to what some scholars argue, the crime of aggression should not be excluded from the Rome Statute. ${ }^{231}$ Some argue that the crime of aggression does not consistently create an individual victim, but rather victimizes the state as a whole. ${ }^{232}$ As a result, they insist that the Rome Statute refrain from including the crime of aggression within its jurisdiction and that it should be dealt by the responsible states, while in no way impairing the ICC's exercise of jurisdiction over the other core crimes within the Rome Statute. ${ }^{233}$ Such opinions have gone too far. They neglect the basic point that the ICC deals with the individual criminal responsibility not with the state.

231 James Nicholas Boeving, 584-588, 610.

232 Ibid.

233 Ibid, 611. 


\section{Bibliography}

\section{BOOKS}

Antonio Cassese. International Law, $2^{\text {nd }}$ ed. Oxford: Oxford University Press, 2005.

, Paola Gaeta, and John R.W.D. Jones. The Rome Statute of the International Criminal Court: A Commentary, Oxford University Press, 2002.

Arieh J. Kochavi, Prelude to Nuremberg, Allied War Crimes Policy and the Question of Punishment. London: University of North Carolina Press, 1998.

Christine Gray. International Law and the Use of Force, $2^{\text {nd }}$ ed. Oxford: Oxford University Press, 2004.

Dae-Soon, Kim. International Law. Seoul: Pakryoung-Sa, 2005.

Dinstein, Yoram. War, aggression and self-defence, $3^{r d}$ ed. Cambridge: Cambridge University Press, 2001.

In-Seop, Chung. Understanding of International Law. Seoul: Hongmun-Sa, 1996.

Ian Brownlie. International Law and the Use of Force by States, Oxford: Clarendon Press. 1963 (reprinted 1991.)

Principles of Public International Law. Oxford: Clarendon Press, 1990.

Jack L. Goldsmith \& Eric A. Posner. The Limits of International Law. Oxford: Oxford University Press, 2005.

Maurizio Ragazzi. The Concept of International Obligations ERGA OMNES. Oxford: Clarendon Press, 2000.

Mauro Politi \& Giuseppe Nesi, The International Criminal Court and the Crime of Aggression: Ashgate, 2004.

Peter Malanczuk. Akerhurst's Modern Introduction to International Law, $7^{\text {th }}$ ed. New York: Routledge, 1998.

Oscar Schachter. International Law in Theory and Practice. London: Martinus Nijhoff Publishers, 1991.

Robert McCorquodale \& Martin Dixon. Cases and Materials on International Law, $4^{\text {th }}$ ed. Oxford: Oxford University Press, 2003.

Rosalyn Higgins. Problems and Process -International Law and How We Use It. Oxford: Clarendon Press, 1995.

\section{ARTICLES}

Andreas L. Paulus, "Peace Through Justice? The Future of The Crime of Aggression in a Time of Crisis," 50 Wayne L. Rev. 1, Spring, 2004.

Benjamin B. Ferencz, “Can Aggression be deterred by Law?” 11 Pace Int'l L. Rev. 341, Fall, 1999. 
Claus Kress, "The German Chief Federal Prosecutor's Decision not to investigate the Alleged Crime of Preparing Aggression against Iraq -note and comment,”2 J. Int'l Crim. Just. 245, June. 2004.

, "The Iraqi Special Tribunal and the Crime of Aggression,” 2 J. Int'l Crim. Just. 347, June. 2004.

David J. Scheffer, "The United States and the International Criminal Court," 93 Am. J. Int'l L. 12, January, 1999.

Elizabeth Wilmshurst, "Definition of the crime of aggression: state responsibility or individual criminal responsibility?" in The International Criminal Court and the Crime of Aggression, ed. Mauro Politi and Giuseppe Nesi, ashgate, 2004

Giorgio Gaja, "The Long Journey towards Repressing Aggression," in Rome Statute of the International Criminal Court: A Commentary, ed. Antonio Cassese ie., Oxford University Press, 2002.

Giuseppe Nesi, "An Outsider;s View" in The International Criminal Court and the Crime of Aggression, ed. Mauro Politi and Giuseppe Nesi, ashgate, 2004.

Grant M. Dawson, "Defining substantive crimes within the subject matter jurisdiction of the international criminal court: what is the crime of aggression?," 19 N.Y.L.Sch. J.Int 'l \& Comp. L. 413, 2000.

Hnas-Peter Kaul, "The crime of aggression: Definitional options for the way forward", in The International Criminal Court and the Crime of Aggression, ed. Mauro Politi and Giuseppe Nesi, ashgate, 2004.

Ioana Gabriela Stancu, "Defining the Crime of Aggression of Redefining Aggression?" in The International Criminal Court and the Crime of Aggression, ed. Mauro Politi and Giuseppe Nesi, ashgate, 2004.

James Nicholas Boeving, "Aggression, International Law, and the ICC: an Argument for the Withdrawal of Aggression from The Rome Statute," 43 Colum. J. Transnat'l L. 557, 2005

Jennifer Trahan, "Defining 'Aggression': Why the Preparatory Commission for the International Criminal Court has faced such a Conundrum,” 24 Loy. L.A. Int'l \& Comp. L. Rev. 439, 2002.

J. Holmes Armstead Jr., "The International Criminal Court: History, Development and Status," 38 Santa Clara L. Rev. 745, 1998.

Linda Jane Springrose, "Aggression as a Core Crime in the Rome Statute establishing an International Criminal Court,” 99 St. Louis-Warsaw Transatlantic L.J. 151, 1999.

Marja Lehto, "The ICC and the Security Council: About the Argument of Politicization" in The International Criminal Court and the Crime of Aggression, ed. Mauro Politi and Giuseppe Nesi, Ashgate, 2004

Mohammed M. Gomaa, "The Definition of the Crime of Aggression and the ICC Jurisdiction over that Crime" in The International Criminal Court and the Crime of Aggression, ed. Mauro Politi and Giuseppe Nesi, ashgate, 2004.

Mauro Politi, "The Debate within the Preparatory Commission for the International Criminal Court", in The International Criminal Court and the Crime of Aggression, ed. Mauro Politi and Giuseppe Nesi, ashgate, 2004.

Muhammad Aziz Shukri, "Will Aggressors ever be tried before the ICC?" in The International Criminal Court and the Crime of Aggression, ed. Mauro Politi and Giuseppe Nesi, ashgate, 2004. 
Paula Escarameia, "The ICC and the Security Council on Aggression" in The International Criminal Court and the Crime of Aggression, ed. Mauro Politi and Giuseppe Nesi, Ashgate, 2004.

Phani Dascalopoulou-Livada, "Aggression and the ICC: Views on Certain Ideas and their Potential for a Solution" in The International Criminal Court and the Crime of Aggression, ed. Mauro Politi and Giuseppe Nesi, ashgate, 2004.

Rachel Peirce, "Which of the Preparatory Commission's Latest Proposals for the Definition of the Crime of Aggression and the Exercise of Jurisdiction should be adopted into the Rome Statute of the International Criminal Court?" 15 BYU J. Pub. L. 281, 2001.

Richard L. Griffiths, "International Law, the Crime of Aggression and the Ius Ad Bellum," International Criminal Law Review 301, 2002.

Saeid Marzaee Yengejeh, "Reflections on the Role of the Security Council in Determining an Act of Aggression" in The International Criminal Court and the Crime of Aggression, ed. Mauro Politi and Giuseppe Nesi, Ashgate, 2004

Sang-Hyun Song, "The Rome Statute and International Criminal Court(ICC) -Challenges and Opportunities," Journal of Law 44 no.3, SNU 2003.

Silvia A. Fernandez de Gurmendi, "The working group on aggression at the preparatory commission for the international criminal court", 25 Fordham Int;l L.J. 589, 2002.

Tae-Hyun Choi, "Definition of the Crime of Aggression within the Jurisdiction of the International Criminal Court," Journal of KSIL 47, no.3, 2002.

Theodor Meron, "Defining Aggression for the International Criminal Court", 25 Suffolk Transnat'l L. Rev. 1, winter, 2001.

Umberto Leanza, "The Historical Backgroud" in The International Criminal Court and the Crime of Aggression, ed. Mauro Politi and Giuseppe Nesi, ashgate, 2004.

Willam A. Schabas, "Origins of the Criminalization of Aggression: how crimes against peace became the 'supreme international crime' in The International Criminal Court and the Crime of Aggression, ed. Mauro Politi and Giuseppe Nesi, ashgate, 2004.

Young Sok Kim, "The Preconditions to the Exercise of the Jurisdiction of the International Criminal Court: With focus on article 12 of the Rome Statute," 8 J. Int'l L. \& Prac. 47, Spring, 1999.

"General Principle of the Criminal Law in the Statute of the International Criminal Law", Mofat Int'l L. Rev, vol. 2. 2003

\section{DOCUMENTS}

\subsection{TREATIES}

Rome Statute of the International Criminal Court, U.N. Doc. A/CONF.183/9 
Versailles Treaty of Peace with Germany, 1919, Peace Treaties, 1265 (in Yoram Dinstein. War, Agression and Self-Defence, $3^{\text {rd }}$ ed., 2001, p.106.)

\subsection{CASES}

Military and Paramilitary Activities in and against Nicaragua (Nicaragua v. United States of America), Merits, Judgment of 27 June 1986, ICJ Reports 1986

North Sea Continental Shelf, Merits, ICJ Reports 1969

The Certain Expenses of the United Nations (Article 17, Paragraph 2, of the Charter), Advising Opinion of 20 July 1962, Case Summaries, http://www.icj-cij.org (accessed April 6, 2006)

\subsection{ICC and UN Documents}

United Nations General Assembly Resoultion 3314 (XXIX), U.N. GAOR, $6^{\text {th }}$ Commission, $29^{\text {th }}$ Session, $2319^{\text {th }}$ Plen. Mtg. 1974.

Affirmation of the Principle of International Law recognized by the Charter of the Nurenberg Tribunal, G.A. Res. 95(1), U.N. GAOR, ${ }^{\text {st }}$ Session, 55 ${ }^{\text {th }}$ Plen. Mtg., 1946.

G.A. Res. 177( II ), U.N. GAOR, $2^{\text {nd }}$ Session., U.N. Doc. A/519, 1947.

G.A. Res. 377(V), U.N. GAOR, $5^{\text {th }}$ Session, Supp. No.20., 302d plen. Mtg., U.N. Doc. A/1775, 1950.

U.N. Doc. A/RES/688(VII), U.N. GAOR. Suppl. 20(A/2361)

ILC Draft Code of Offences Against the Peace and Security of Mankind, in YILC vol. II, 1954.

ILC Draft Code of Offences Against the Peace and Security of Mankind, in YILC vol. II(2), 1996.

Report of the International Law Commission on the work of its $46^{\text {th }}$ Session, U.N. GAOR, $49^{\text {th }}$ Sess., Supp. No.10, U.N.Doc A/49/10 1994

Report of the Preparatory Committee on the Establishment of an International Criminal Court, U.N. Doc. $\mathrm{A} / 51 / 22,1998$

First Session (First and Second Resumptions) Draft Report of the Assembly of States Parties to the Rome Statute of the International Criminal Court, U.N. Doc. ICC-ASP/1/L.5, 2003

Third session, Special Working Group on the Crime of Aggression, U.N. Doc. ICC=ASP/3/SWGCA/INF.1 2004, p7

Fourth Session, Special Working Group on the Crime of Aggression, U.N. Doc. ICC-ASP/4/SWGCA/INF.1, 2005, p7 8, 10;

Discussion paper proposed by the Coordinator, U.N. Doc. PCNICC/2002/WGCA/RT.1 /Rev.1, 2002 ; PCNICC/2002/Add.2 2002

Compilation of Proposlas on the crime of aggression submitted at the Preparatory Committee on the Establishment of an International Criminal Court(1996 1998), the United Nations Diplomatic Conference of Plenipotentiaries on the Establishment of an International Criminal Court(1998) and the Preparatory 
Commission for the International Criminal Court (1999), U.N. Doc. PCNICC/1999/INF/2 1999

Proposal submitted by Bahrain, Iraq, Lebanon, the Libyan Arab Jamahiriya, Oamn, the Sudan, the Syrian Arab Republic and Yemen on the crime of aggression, U.N. Doc. PCNICC/1999/DP.11 1999

Proposal submitted by the Russian Federation: definition of the crime of aggression U.N. Doc. PCNICC/1999/DP.12 1999

Proposal submitted by Germany: definition of the crime of aggression U.N. Doc. PCNICC/1999/DP.13 1999

Proposal submitted by Greece and Portugal, U.N. Doc. PCNICC/1999/WGCA/DP.1 1999

Proposal submitted by Germany: the crime of aggression - a further informal discussion paper, U.N. Doc. PCNICC/2000/WGCA/DP.4 2000

Proposal submitted by Greece and Portugal, U.N. Doc. PCNICC/2000/WGCA/DP.5 2000

Proposal submitted by Colombia on the definition of the crime of aggression and on condition for the exercise of the jurisdiction of the Court with regard to this crime, U.N. Doc. PCNICC/2000/WGCA/DP.1 2000

Proposal submitted by Bosnia and Herzegovina, New Zealand and Romania, Definition of the crime of aggression, U.N. Doc. PCNICC/2001/WGCA/DP.2 2001

Proposal submitted by Samoa, Elements of the Crime of aggression U.N. Doc. PCNICC/2002/WGCA/DP.2 2002

Proposal submitted by Cuba, Definition of the crime of aggression and conditions for the exercise of jurisdiction, U.N. Doc. ICC-ASP/1/L.4 2003 